\title{
A review of female cattle reproduction with special reference to a comparison between buffaloes, cows and zebu
}

\section{Hilary Dobson and Maneewan Kamonpatana*}

Department of Veterinary Clinical Science, University of Liverpool, Leahurst, Neston, South Wirral L64 7TE, U.K. and *Biochemistry Unit, Faculty of Veterinary Science, Chulalongkorn University, Henri Dunant Street, Bangkok 10500, Thailand

\section{Contents}

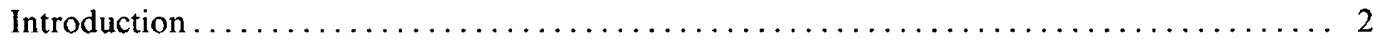

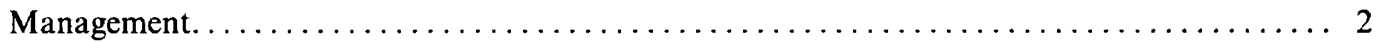

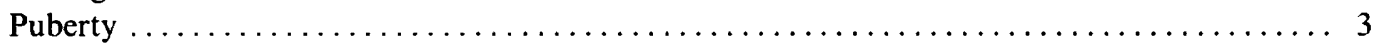

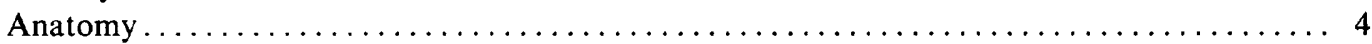

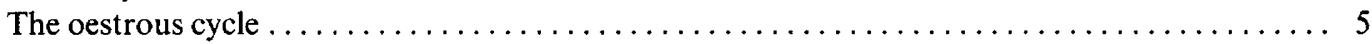

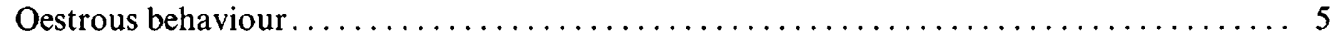

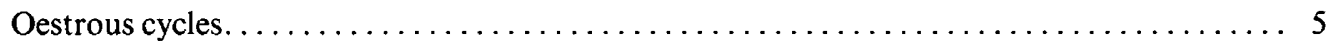

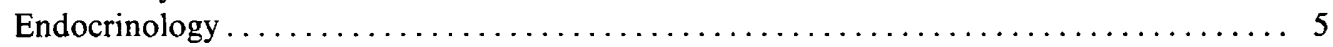

Temporal relationships around oestrus $\ldots \ldots \ldots \ldots \ldots \ldots \ldots \ldots \ldots \ldots \ldots \ldots$

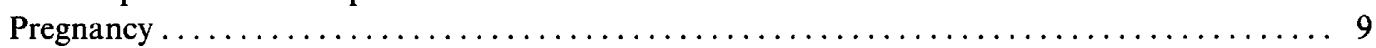

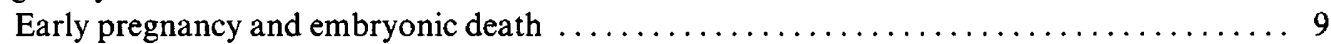

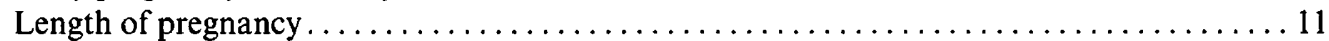

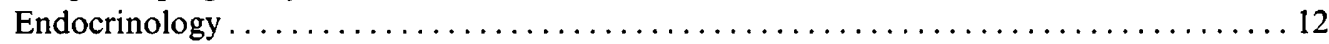

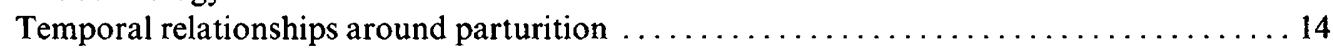

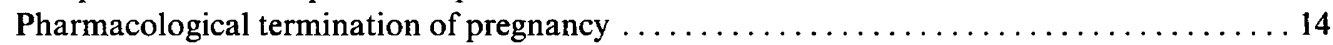

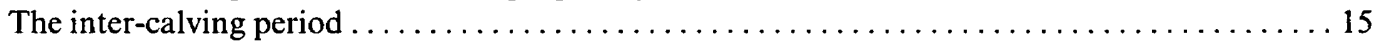

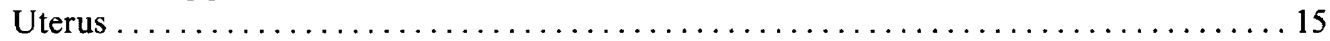

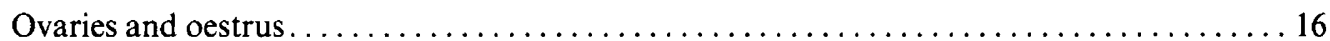

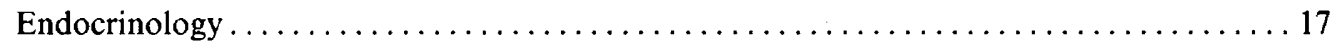

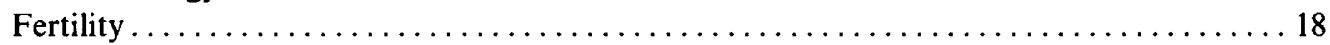

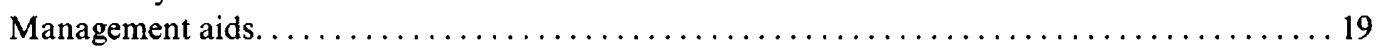

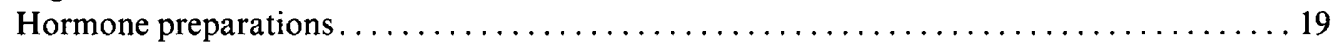

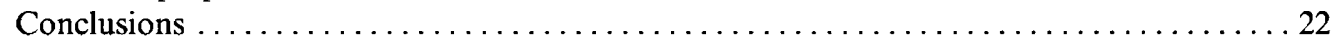

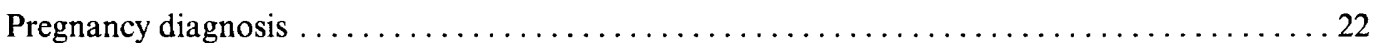

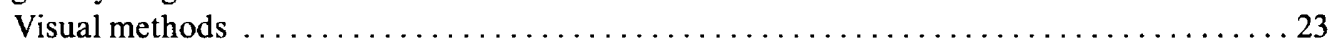

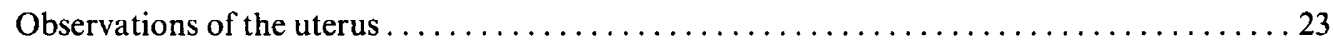

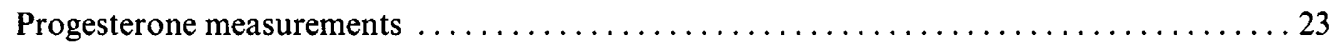

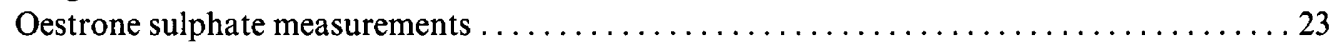

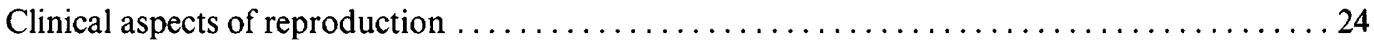

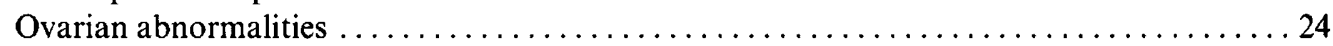

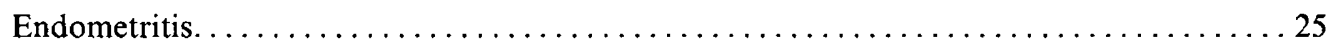

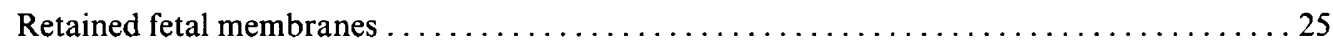

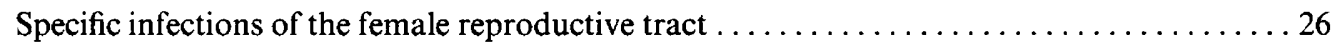

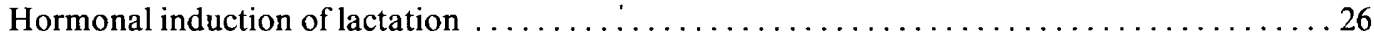

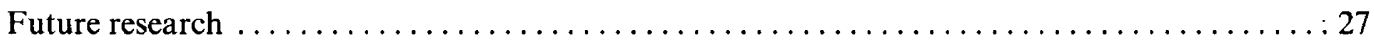

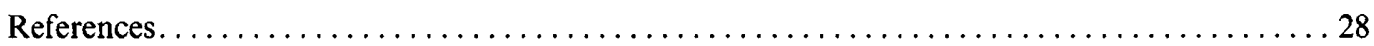




\section{Introduction}

In the order Artiodactyla, the cloven-hooved mammals, there are a number of families and cattle belong to the genus Bos within the Family Bovidae. All modern cattle have developed by natural selection into many distinct species including, amongst others, Bubalus bubalis, the domesticated Asian buffalo, Bos taurus, the domesticated cow of Europe, and Bos indicus, the domesticated zebu of India/Asia and Africa.

Improved buffalo and zebu production could significantly enhance the economy and living standards of many rural communities throughout the world. The purpose of this present review is not to cite every publication concerning cattle but rather to highlight both the similarities and differences between buffaloes, cows and zebu in an attempt to emphasize areas in which greatest gains are to be made in the future of the unrealized potential of the buffalo and zebu compared to the highly developed Western cow. Care must be taken to substantiate in great detail the similarities and differences between the species before blindly applying techniques known to be successful for cows to buffaloes and zebu.

During its development the cow has been directed in two separate ways to satisfy the demands of (a) the dairy industry by concentrating on the production of large amounts of milk, and (b) the beef industry by emphasizing low-cost meat production. As a consequence certain aspects of reproductive efficiency are differently affected between beef and dairy cows and when relevant these will be pinpointed.

The diploid chromosome number of bovids varies from 30 to 60 but the fundamental number varies only from 58 to 62 . This indicates an almost exclusive use of the Robertsonian translocation mechanism of karyotype evolution (Wurster \& Benirscke, 1968). The river-type buffalo, e.g. the Murrah from India, has a diploid number of 50 compared to 48 for the swamp-type buffaloes from S.E. Asia. The Murrah has two extra acrocentric chromosomes which are presumably translocated onto the short arms of the number 1 autosome of the swamp buffalo. Differential staining shows that Egyptian water buffaloes, with a diploid number of 50, are closely related to Murrah buffalo (Cribiu \& Obeidah, 1978). Hybridization between Murrah and swamp buffaloes is possible and the hybrids are fertile.

The diploid number for the cow and the zebu is 60 and, although they hybridize with each other, neither voluntarily interbreeds with buffaloes. Differential $\mathrm{C}$ band and $\mathrm{G}$ band staining is similar for both species (Potter, Upton, Cooper \& Blackshaw, 1979), but biochemical evidence confirms that they are distinct species despite their lack of reproductive isolation (Manwell $\&$ Baker, 1980).

There are at least 30 different zebu breeds in the Indian continent alone; the Hariana breed is a common dairy animal in India, with Sahiwal and Red Sindhi being more prevalent in Pakistan. Other breeds include the Afrikander of South Africa, the Sanga and Agoni of Middle Africa, the Fulani of Nigeria, and the Brahman which is a zebu breed developed in the U.S.A. from Indian and Brazilian stock. There are about $130 \times 10^{6}$ buffaloes in the world with the largest population in India and China. Murrah buffaloes are used as dairy, work and meat animals whereas the smaller swamp buffalo is a major work animal but gives little milk. In India, Pakistan and Egypt the buffalo is a dairy animal, producing milk with a very high fat percentage $(8 \%)$ compared to the cow $(4 \%)$. The adaptation of buffalo and zebu to tropical climates ensures their place in the future of world agriculture. However, one of the major factors limiting more efficient utilization of these species is their low reproductive efficiency, a biological phenomenon closely linked with managerial problems.

\section{Management}

Domestication of any species is likely to affect the production efficiency, and cattle are no exception. The majority of buffaloes and zebu are kept in small numbers and are accustomed to 
individual attention, being groomed and massaged, and hand-fed. In hot climates there must be allowance for shade or wallowing, or a routine of sluicing or spraying. The plastering of mud which (swamp) buffaloes acquire in the wallows gives some protection against biting flies and against the rays of the sun. This is an important factor in the heat-control mechanism, since buffaloes have few sweat glands.

In contrast, cows in Western societies are managed in herds of much greater numbers; in England and Wales in 1979/1980 the average dairy herd size was 50 cows/herd but over $39 \%$ of the cows were maintained in herds of $>100$ cows (Milk Marketing Board, 1980). The average estimated milk yield per cow was 4600 litres over 305 days; this contrasts sharply with $1400-1850$ litres over a total lactation of 270 days for the Murrah buffalo and only 230-870 litres for the swamp buffalo. Apart from advances made by genetic selection, Western dairy cows are placed under great stress for milk production and as a result are in negative energy balance for at least some of the lactation period. These excessive demands have marked effects on the cows and $25 \%$ are culled 'for reproductive reasons' (Young et al., 1983); 35\% of problem cows had cystic ovaries, but only $1.0 \%$ endometritis. Similar analysis for causes of subfertility in buffaloes and zebu reveals a completely different picture: there is a long post-partum interval to fertile heat and the incidence of endometritis can be as high as $20 \%$ (Rao, 1981; Rao \& Sreemannarayana, 1982). Suckling of buffalo and zebu calves is also prevalent for much longer periods than in cow herds. It is important to remember that these management factors will affect reproductive efficiency as well as any species differences. This is also obvious when comparing the two types of cows: many beef breeding units are maintained in a free-range suckling system on moderately poor pasture and so nutritive stresses are important. The differences attributable to suckling will be dealt with in more detail during consideration of the endocrinology of the post-partum period.

\section{Puberty}

The attainment of puberty depends largely on body weight (Sorensen et al., 1959). In wellnourished buffaloes the first signs of oestrus occur at 15-18 months of age and $198 \mathrm{~kg}$ body weight, although in field conditions puberty has been reported at 24-36 months (Bhattacharaya, 1974). Once oestrous cycles are initiated oestrus appears with normal regularity. The first calving of buffaloes occurs at a body weight of about $480 \mathrm{~kg}$ between 33 and 45 months although many do not calve until much later (Lundström, Abeygunawardena, de Silva \& Perera, 1982).

In cows puberty is attained at about $7-12$ months and $250-300 \mathrm{~kg}$ body weight. First service is usually delayed to about 15 months, with consequent calving at 24-36 months. Puberty occurs at a later age in zebu, and at a higher percentage of adult body weight. Corpora lutea are palpable in well-fed heifers at 14-24 months (Plasse, Warnick \& Koger, 1968b). However, there have been other exceptional reports of first oestrus not occurring until 42-52 months. Oyedipe, Osori, Akerejola \& Saror (1982) reduced the age at puberty by improved protein feeding and achieved conception rates of $58.8 \%$ over a 90 -day breeding period at an average of 21 months.

Little is known concerning the precise effect of level of nutrition, or growth rates, on puberty in buffaloes. In cows variations in food intake affect the age at which puberty is attained (Wiltbank, Kasson \& Ingalls, 1969) although some factor(s) other than weight may be involved. Short \& Bellows (1971) have also shown that there is a higher pregnancy loss in poorly-fed heifers and heavy losses in subsequent milk production also occur.

Data are also very scarce concerning endocrine characteristics in pre- and post-pubertal buffalo and zebu heifers. It is not known whether the delay in expression of the first oestrus is due to inadequate growth rates or to very poor expression of the first oestrus at the start of ovarian cyclicity. Establishment of optimum growth rates and a greater understanding of the endocrinology of puberty may increase reproductive efficiency of buffaloes and zebu. 
Detailed endocrine studies of cow heifers (Gonzalez-Padilla, Wiltbank \& Niswender, 1975a; Schams, Schallenberger, Gombe \& Karg, 1981) have revealed low plasma luteinizing hormone $(\mathrm{LH})$ values $(1.0 \mathrm{ng} / \mathrm{ml})$ at birth with a subsequent marked fluctuation around $3 \mathrm{ng} / \mathrm{ml}$ occurring before puberty. Progesterone concentrations were very low until the first oestrus was detected. After first oestrus, normal luteal patterns, with plasma progesterone values reaching $4 \mathrm{ng} / \mathrm{ml}$, were observed. Measurements of endogenous peripheral values of follicle-stimulating hormone (FSH) and prolactin have so far been unhelpful. Oestradiol concentrations, typical of mature cows, increased over the period 8 days before puberty (Glencross, 1984).

Once the hypothalamus-pituitary axis has matured in response to body weight, progesterone plays a key role in the changes leading to puberty. Injections of oestradiol evoked a release of LH in prepubertal heifers but normal corpora lutea were formed only in those animals pre-treated with progesterone (Gonzalez-Padilla, Niswender \& Wiltbank, 1975b). While the age at first oestrus can be controlled to a certain extent by feeding this is not always the most economical/practical approach. Gonzales-Padilla, Riuz, LeFever, Denham \& Wiltbank (1975c) have achieved acceptable conception rates after oestradiol-progestagen treatments. Little is known for bovine species about body weight and the maturation of the hypothalamic axis, although studies are beginning in sheep (Foster, Yellon \& Olster, 1984).

\section{Anatomy}

There is a considerable similarity in the anatomy of the reproductive organs of buffaloes, cows and zebu. The smaller total body size of buffaloes compared to cows reflects the small size of most buffalo organs (Table 1). There are insufficient available data for zebu.

The ovaries are ovoid and small follicles are always present at the surface. The developing corpus luteum of the buffalo is pinkish grey in colour, with red veining (not normally yellow as in the cow). The red veining disappears in the regressing corpus luteum which finally becomes dull grey in colour.

The gross anatomy of the oviducts and bicornuate uterus is similar but the cervix of the buffalo is narrower and the lumen more tortuous than in the cow. There are similar cyclic changes in the uterine endometrium during the oestrous cycle; cell height increases after ovulation to mid-cycle, then declines again (Ghannam \& Deeb, 1966). In each species there are also cyclic changes in vaginal smears, cervical mucus ferning patterns, body temperature and $\mathrm{pH}$ but these are not useful for predicting the time of ovulation very reliably.

Table 1. Dimensions of the reproductive tract in female buffaloes and cows (data from Aboule-Fadle, Fahmy \& El-Shafey, 1974a, b; Luktuke \& Rao, 1962; Mobarak, 1969)

\begin{tabular}{lcc}
\hline & Buffaloes & Cows \\
\hline Adult bodyweight $(\mathrm{kg})$ & $350-500$ & 700 \\
Adult withers height $(\mathrm{cm})$ & 125 & 135 \\
Ovary length $(\mathrm{cm})$ & $2 \cdot 2-2 \cdot 9$ & $2 \cdot 8-3 \cdot 8$ \\
Ovary weight $(\mathrm{g})$ & $3 \cdot 0-4 \cdot 0$ & $5 \cdot 0-9 \cdot 4$ \\
Diameter of biggest follicle $(\mathrm{cm})$ & $1 \cdot 4-1 \cdot 7$ & $1 \cdot 9-2 \cdot 2$ \\
Diameter of mature corpus luteum $(\mathrm{cm})$ & $1 \cdot 3-1 \cdot 6$ & $1 \cdot 7-3 \cdot 0$ \\
Weight of mature corpus luteum $(\mathrm{g})$ & $0 \cdot 7-1 \cdot 5$ & $1 \cdot 2-2 \cdot 5$ \\
Diameter of ovum $(\mu \mathrm{m})$ & 169 & 169 \\
Oviduct length $(\mathrm{cm})$ & $19-23$ & $25-26$ \\
Uterus length $(\mathrm{cm})$ & $30-38$ & $35-45$ \\
Uterine body diameter $(\mathrm{cm})$ & $2 \cdot 1-2 \cdot 8$ & $2 \cdot 5-5 \cdot 0$ \\
\hline
\end{tabular}




\section{The oestrous cycle}

\section{Oestrous behaviour}

Homosexual activity in buffaloes and zebu is not as pronounced as in cows (Hafez, 1954; Rahka, Igboeli \& Hale, 1970). The duration of oestrous symptoms ranges from 11.92 to $28.47 \mathrm{~h}$ in buffaloes compared with 12.5 to $27.8 \mathrm{~h}$ in cows but the intensity of signs is lower in buffaloes (El-Sheikh \& El-Fouly, 1971; Kanai \& Shimizu, 1983). Singh, Singh, Sharma \& Sharma (1984) suggest that vulval discharge of clear mucus, especially in the recumbent animal, is the most reliable single sign of oestrus available to the buffalo stockman.

In the cow, 'standing to be mounted' is the most useful single sign used by dairy herdsmen (Williamson, Morris, Blood, Cannon \& Wright, 1972a). Copious quantities of clear elastic mucus flow from the vulva; the latter becomes swollen and reddened at oestrus. Inadequate detection of oestrus and presentation of cows for artificial insemination (AI) at the wrong time during oestrus are the prime problems limiting the reproductive efficiency of cows.

\section{Oestrous cycles}

The day of oestrus is designated as Day 0 . The length of the oestrous cycle is very similar in each species; buffaloes have a mean ( \pm s.e.) cycle length of $21.6 \pm 0.23$ days; for cows and zebu values of $21.28 \pm 0.06$ days have been reported with $85 \%$ in oestrus between 18 and 22 days (Asdell, 1964). The duration of the oestrus in each species is variable being $10-30 \mathrm{~h}$. Ovulation occurs spontaneously about $10 \mathrm{~h}$ after the end of oestrus (Asdell, 1964; Adeyemo, Heath, Steinbach \& Adadevoh, 1979).

Buffaloes and zebu are characterized by a marked seasonal pattern of breeding (Jöchle, 1972; Roy, Bhattacharya \& Luktuke, 1972). The female is sexually inactive from March to the end of June although there is a claim that the duration of oestrus in buffaloes during early summer is shorter and this may be mistaken for anoestrus. Buffalo females can come into oestrus and conceive (calving percentage as high as $80 \%$ ) under rigorous summer conditions provided that the animals are well sluiced, allowed to wallow and provided with shade (Roy et al., 1968; Mehta, Gangwar, Srivastava \& Dhingra, 1979). Swamp buffaloes of Malaya have oestrous periods all year but more regularly in hot weather, April-July (Asdell, 1964).

There has been an indication that breeding efficiency in dairy cows (Bulman \& Lamming, 1978) and beef cows (Peters \& Riley, 1982) is seasonal in Britain but in temperate climates this has not been a serious handicap to the dairy or beef industry.

Hours of daylight are important in controlling seasonality in cows but other factors include temperature and nutrition. Similarly for buffaloes and zebu, but other correlated environmental factors, e.g. temperature, rainfall and food supply, appear to be of overriding importance (Rahka \& Igboeli, 1971; Jöchle, 1972).

In regions such as Egypt and India, where daylight increases with ambient temperature (especially greater than $25^{\circ} \mathrm{C}$ ), ovarian activity and expression of oestrus is greater in cooler winter months with short daylength (El-Fouly, Kotby \& El-Sobhy, 1976a). Rao \& Pandey (1983) measured lower plasma concentrations of glucocorticoids in buffaloes during the hotter months as did Lee, Roussel \& Beatty (1976) in cows. In buffaloes there are also lower plasma progesterone values (Kaur \& Arora, 1984) and a lowered LH response to gonadotrophin-releasing hormone $(\mathrm{GnRH})$ injections in the hotter months (Aboul-Ela, El-Keraby \& Chesworth, 1983). Further efforts appear necessary to understand the mechanisms by which heat stress reduces reproductive efficiency in buffaloes and zebu.

\section{Endocrinology}

Progesterone. The concentration in the peripheral blood of swamp and Murrah buffaloes is low at oestrus (Day 0: 0.13-0.27 ng/ml) and does not rise until after Day 5 (Fig. la). Values increase 

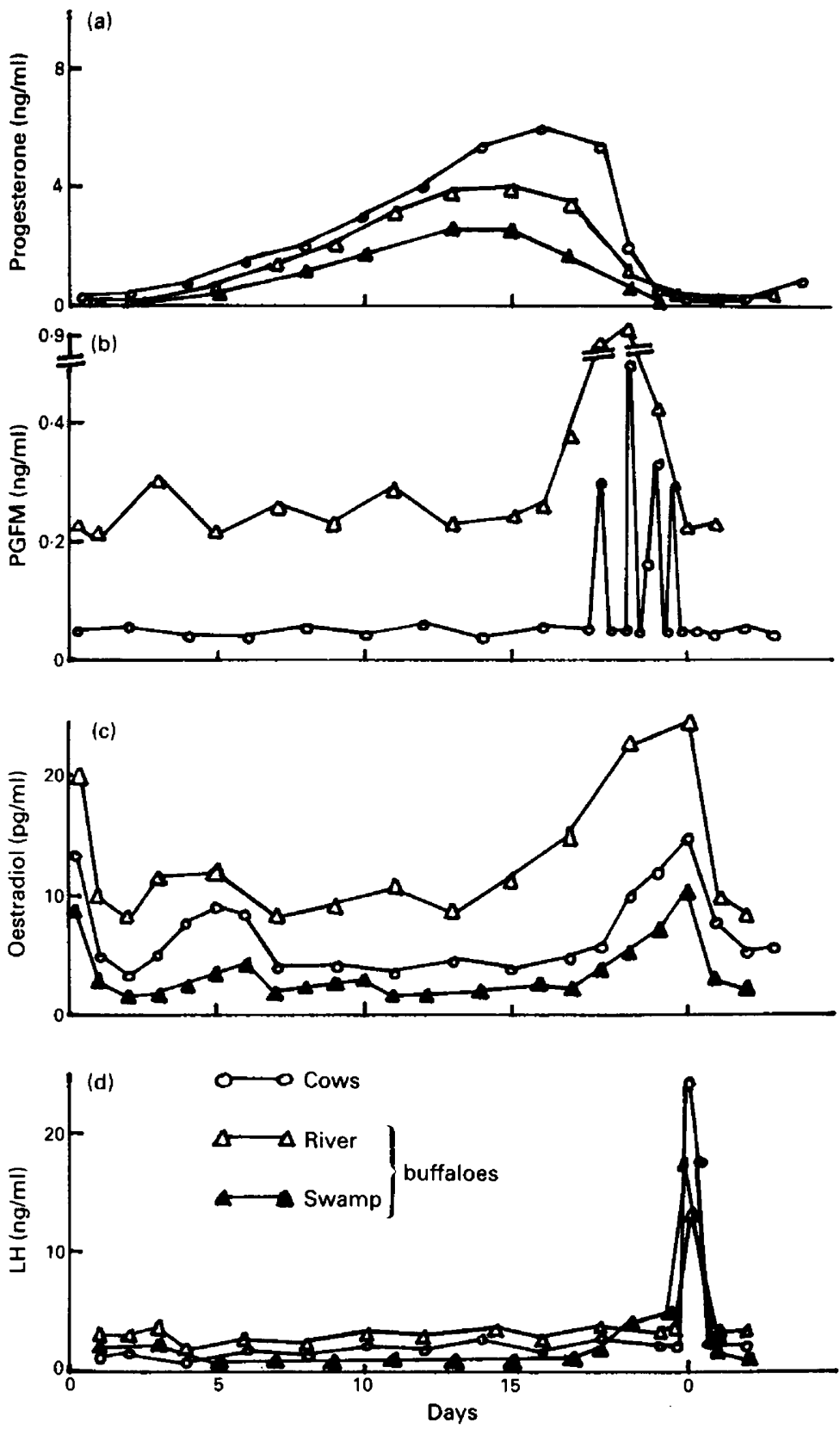

Fig. 1. Peripheral plasma concentrations of (a) progesterone, (b) PGFM, (c) oestradiol, and (d) LH during the oestrous cycle of river $(\triangle)$ and swamp $(\Delta)$ buffaloes and of cows $(O)$. Data for river buffalo after Arora \& Pandey (1982a) and Batra \& Pandey (1983a); for swamp buffalo after Kanai \& Shimizu (1984); and for cows after Dobson \& Dean (1974), Kindahl et al. (1976) and Dobson (1978a). 
until Day 14-16 with a lower mean value of $1.51-2.6 \mathrm{ng} / \mathrm{ml}$ in swamp buffalo (Kamonpatana et al., 1979b; Jainudeen, Bongso \& Tan, 1982; Kanai \& Shimizu, 1984) compared to values of $4 \cdot 00-4 \cdot 26 \mathrm{ng} / \mathrm{ml}$ in Murrah buffaloes (Bachlaus, Arora, Prasad \& Pandey, 1980; Arora \& Pandey, 1982a). This is a real difference between breeds and is reflected in milk fat and whole milk progesterone measurements (Kamonpatana, Ngramsuriyaroj, Srisakwattana \& Chantaraprateep, 1983a).

A heat-stress influence on peripheral plasma progesterone may be mediated by the level of nutrition. Kaur \& Arora (1984) found lower progesterone values and an onset of ovarian inactivity during hotter months in buffalo fed sub-optimally, compared with similar animals receiving adequate nutrients.

Profiles of plasma progesterone are similar in dairy and beef cows although even greater luteal values of $6.0-7.0 \mathrm{ng} / \mathrm{ml}$ have been reported (Stabenfeldt, Ewing \& McDonald, 1969; Donaldson, Bassett \& Thorburn, 1970). Frequent sampling of vena cava blood has revealed pulsatile release of progesterone from the ovary (Walters, Schams \& Schallenberger, 1984). The onset in the decline of progesterone values is variable, commencing between Days 16 and 19 . Once the drop occurs it is always precipitous with the interval to the onset of oestrus ranging from 1 to 5 days. This latter variability is attributed to the time required for development and maturation of ovulatory follicles. The concentration of progesterone in the peripheral plasma of non-pregnant zebu is very similar (Days 9-12: $4.5 \pm 1.03 \mathrm{ng} / \mathrm{ml}$ ) to that of cows in the same environment (Adeyemo \& Heath, 1980).

The concentration of progesterone in milk parallels that in plasma. In Murrah buffaloes, whole milk values at oestrus range from 0.5 to $4.17 \mathrm{ng} / \mathrm{ml}$ and luteal-phase values range from 18.0 to $24.75 \mathrm{ng} / \mathrm{ml}$ (Batra, Arora, Bachlaus \& Pandey, 1979; Arora, Batra, Pahwa, Jain \& Pandey, 1980; Singh \& Puthiyandy, 1980) where in oestrous cows whole milk values range from $0 \cdot 1$ to $4 \mathrm{ng} / \mathrm{ml}$, with luteal-phase values of $10-60 \mathrm{ng} / \mathrm{ml}$ (Dobson, Midmer \& Fitzpatrick, 1975; Bulman \& Lamming, 1978). Reports of milk progesterone values for zebu are not yet available.

Oxytocin. Measurements of oxytocin in the cow show that the circulating values increase to a maximum of $6.4 \mathrm{pg} / \mathrm{ml}$ and decrease in synchrony with changes in progesterone concentration, falling to a minimum at oestrus $(0.5 \mathrm{pg} / \mathrm{ml}$ : Schams, 1983). The presence of oxytocin in the corpus luteum suggests that the changing blood concentrations during the cycle reflect luteal biosynthesis, and there is now considerable evidence that oxytocin is involved in the control of luteolysis (Wathes, 1984). Ovarian oxytocin content is greatly reduced in pregnant cows. No studies have yet been carried out in buffaloes or zebu.

Oestradiol. The pattern of plasma oestradiol appears similar in buffaloes and cows, with minimum values occurring during the mid-luteal phase. Concentrations begin to rise 4-5 days before oestrus to maximum concentrations on Day 0 (Fig. 1c). Some reports (Dobson \& Dean, 1974; Glencross \& Pope, 1981) refer to further increases during the early luteal phase, Days 5-7, reflecting follicular growth at this time (Rajakoski, 1960). It has been reported that Murrah buffaloes have higher overall plasma oestradiol concentrations than do swamp buffaloes and cows. Values in the luteal phase of $10-15 \mathrm{pg} / \mathrm{ml}$, and at oestrus of $31.34 \pm 1.70 \mathrm{pg} / \mathrm{ml}$, in Murrah buffaloes (Batra \& Pandey, 1982) compare with the lower values of $2.9 \mathrm{pg} / \mathrm{ml}$ and $9.0-13.0 \mathrm{pg} / \mathrm{ml}$ respectively for swamp buffaloes (Kanai \& Shimizu, 1984; Avenell, Saepudin \& Fletcher, 1985), and 1-6 pg/ml and $10-15 \mathrm{pg} / \mathrm{ml}$ respectively in cows (Dobson \& Dean, 1974; Glencross \& Pope, 1981). This difference may be methodological in origin and so needs substantiation. No oestradiol measurements have far been reported for zebu.

Concentrations of oestradiol in whole milk parallel those in plasma in buffaloes and cows albeit at slightly higher concentrations. Mean mid-luteal phase values of $20-25 \mathrm{pg} / \mathrm{ml}$ and values at oestrus of 45-50 pg/ml have been reported for buffaloes (Batra \& Pandey, 1982) compared to lower values of $15 \mathrm{pg} / \mathrm{ml}$ and $36 \mathrm{pg} / \mathrm{ml}$ at respective stages in cows (Pandey, Pahwa, Suri \& Batra, 1981). This may reflect the higher fat content of buffalo milk (Kay, 1974) as $65 \%$ of milk oestradiol is located in the lipid phase (Wolford \& Argoudelis, 1970) and analyses on defatted cow milk have revealed very similar concentrations to those in plasma (Glencross \& Abeywardene, 1983). 
Prostaglandins. The concentration of 13,14-dihydro-15-keto-prostaglandin F-2 $\alpha$ (PGFM; a major metabolite of PGF-2 $\alpha$ ) increases in buffalo blood from about 250 to $900 \mathrm{pg} / \mathrm{ml}$ over the period 2-3 days before oestrus (Batra \& Pandey, 1983a). The daily profiles in buffalo milk are very similar. The same pattern in plasma has been reported for cows (Fig. 1b) albeit at slightly lower concentrations of $40-100 \mathrm{pg} / \mathrm{ml}$ for baseline values with peaks ranging from $150-570 \mathrm{pg} / \mathrm{ml}$ (Kindahl, Edqvist, Bane \& Granstrom, 1976). Increases in PGFM values occur about the same time as reduction in progesterone values. PGFM values have not yet been reported for zebu.

Detailed studies in cows (Kindahl et al., 1976) have revealed a pulsatile release of PGFM with the first significant rise (baseline $50 \mathrm{pg} / \mathrm{ml}$ increasing to $200-300 \mathrm{pg} / \mathrm{ml}$ ) occurring just before the release of progesterone. However, subsequent PGFM release occurs with greater frequency and amplitude during the continued demise of the corpus luteum. Enucleation of the corpus luteum, or prostaglandin analogue administration before Day 12 of the cycle, does not result in PGFM release (Kindahl, Lindell \& Edqvist, 1980). This does not support the theory that progesterone withdrawal per se is important for PGFM release.

The release of prostaglandins from the uterus appears to be controlled by oestrogens excreted by growing follicles; destruction of bovine follicles by electrocauterization and irradiation prolongs the functional life of the corpus luteum (Villa-Godoy, Ireland, Wortman, Ames \& Fogwell, 1981). Administration of oestradiol to cows during the luteal phase causes luteolysis and increased PGFM concentrations, but is ineffective in hysterectomized animals (Thatcher et al., 1984). No similar studies have been carried out on buffaloes or zebu.

Luteinizing hormone ( $L H)$. Measurements of the gonadotrophins in buffaloes and zebu have been hindered by the unavailability of purified preparations. Hence heterologous assays have been established, expressing results in equivalents of cow LH (usually NIH-LH-B10). During most of the cycle baseline values of $0 \cdot 72-2 \cdot 0 \mathrm{ng} / \mathrm{ml}$ have been recorded in buffaloes with peak values on Day 0 of $20 \cdot 0-40 \cdot 0 \mathrm{ng} / \mathrm{ml}$ (Fig. 1d; Kaker, Razdan \& Galhotra, 1980; Arora \& Pandey, 1982a; Kanai \& Shimizu, 1984; Avenell et al., 1985). Similar values were obtained for zebu by Carr (1972), and for cows by Snook, Saatman, \& Hansel (1971); Schams, Schallenberger, Hoffman \& Karg (1977) and Dobson (1978a).

Attempts have been made to compare LH values in buffaloes in various physiological states; however, with daily sampling regimens significant differences were not detected (Galhotra, Kaker \& Razdan, 1981; Razdan, Kaker \& Galhotra, 1981; Arora \& Pandey, 1982b). This is not surprising as studies in cows and calves have shown differences in LH only after sampling as frequently as every 15 min because of the short-lived LH pulses (Rahe, Owens, Fleeger, Newton \& Harms, 1980; Pelletier, Carrez-Camous \& Thiery, 1981; Schams et al., 1981). Such pulsatile release of LH has not yet been confirmed in buffalo or zebu.

In the cow during the early luteal phase (Day 3) $\mathrm{LH}$ pulses are of low amplitude $(0.3-1.8 \mathrm{ng} / \mathrm{ml})$ and high frequency (20-30 pulses $/ 24 \mathrm{~h}$ ) with each cow exhibiting an inherent rhythm. During the mid-luteal period the pulse amplitude increases $(1 \cdot 2-7 \cdot 0 \mathrm{ng} / \mathrm{ml})$ and the frequency decreases $(6-8$ pulses $/ 24 \mathrm{~h})$. High values of $\mathrm{LH}(15-65 \mathrm{ng} / \mathrm{ml})$ are found at the onset of oestrus $( \pm 8 \mathrm{~h})$ (Niswender, Reichert, Midgley \& Nalbandov, 1969; Schams et al., 1977; Dobson, 1978a).

Throughout this preovulatory surge, LH still fluctuates in a pulsatile manner. There is good evidence from sheep (Goodman \& Karsch, 1981) that modulations of LH frequency and amplitude are governed by progesterone and oestradiol.

Follicle-stimulating hormone ( $F S H)$. Measurements in buffaloes have also depended on expressing results in equivalents of a cow standard, LER-1596-1. Irregular fluctuations occur during the cycle with a mean value of about $12.0 \mathrm{ng} / \mathrm{ml}$ compared with maximum values of about $60.0 \mathrm{ng} / \mathrm{ml}$ on Day 0 (Razdan, Kaker \& Galhotra, 1982). No FSH results are available for zebu.

Studies from cows give results in equivalents of NIH-FSH-B1 but there is great discrepancy in absolute values ranging from 10 to $400 \mathrm{ng} / \mathrm{ml}$ during the luteal phase, with maximum values at oestrus from 78 to $600 \mathrm{ng} / \mathrm{ml}$ (Akbar, Reichert, Dunn, Kaltenbach \& Niswender, 1974; Schams \& Schallenberger, 1976; Dobson, 1978a; Barnes, Kazmer, Brierly, Richardson \& Dickey, 1980). 
There is, however, overall agreement on the pattern of FSH: there is great variation throughout the oestrous cycle with maximum values occurring with the preovulatory $\mathrm{LH}$ surge. A detailed study of changes around oestrus (Dobson, 1978a) revealed a second increase in FSH about $24 \mathrm{~h}$ after the LH surge but this time without $\mathrm{LH}$, suggesting two separate releasing mechanisms for $\mathrm{LH}$ and FSH. The mechanism of release and the role for this second increase in FSH at the time of ovulation are unknown.

\section{Temporal relationships around oestrus}

A greater understanding of precise hormonal changes around behavioural oestrus in buffaloes and zebu may improve the efficiency of detection of oestrus and AI schemes. The follicular phase of the 21 -day oestrous cycle in bovids is relatively short (2-5 days), so blood samples must be collected at least every $4-6 \mathrm{~h}$ to establish detailed hormonal inter-relationships.

The oestradiol increase before oestrus is associated with small but significant increases in $\mathrm{LH}$ (buffaloes: Kanai \& Shimizu, 1984; cows: Rahe et al., 1980). In cows the increase in LH is a reflection of increased frequency of LH pulses which in turn stimulate pulsatile oestradiol production by the ovary (Walters \& Schallenberger, 1984). Jain \& Pandey (1984) have reported that values of oestradiol continue to rise to reach a maximum $8-17 \mathrm{~h}$ before the onset of oestrus in buffaloes using a combination of criteria to establish onset of oestrus. However, it is difficult to be precise about the exact time of oestrus in relation to maximum oestradiol values. This is highlighted by Kaker et al. (1980) who found LH concentrations at the onset of oestrus in only 6 out of 14 buffaloes studied. In the remaining animals $\mathrm{LH}$ surges occurred 4-48 h later, even though a vasectomized bull was used for detection of oestrus.

The duration of raised LH values $>10 \mathrm{ng} / \mathrm{ml}$ is similar, 6-10 h, in buffaloes (Batra \& Pandey, 1982; Avenell et al., 1985), cows (Schams et al., 1977; Dobson, 1978a) and zebu (Carr, 1972).

Oestradiol is the stimulus that triggers oestrous behaviour and the gonadotrophin surge. Exogenous oestradiol induces a preovulatory-like surge of LH in cows (Beck \& Convey, 1977; Peters \& Lamming, 1984) although not in the presence of raised progesterone values (Kesner, Convey \& Anderson, 1981). This effect of oestradiol is mediated at least in part by the release of GnRH from the hypothalamus and in part by increased responsiveness of the pituitary to GnRH. The ability of the pituitary to release $\mathrm{LH}$ and FSH in response to GnRH is increased by raised oestradiol concentrations (Kesner et al., 1981).

In buffaloes and cows LH increases dramatically (the preovulatory surge) at the same time as oestradiol values decline. If human chorionic gonadotrophin (hCG; predominant LH activity) is administered to cows just before oestrus, there is an immediate premature decline in oestradiol values with the formation of a normal corpus luteum (Dobson \& Fitzpatrick, 1975).

While it is to be expected that similar hormone interrelationships occur in buffaloes and zebu, they have not yet been proved. Although it may not be necessary to confirm every interaction, great care must be taken in studies on buffaloes and zebu to use physiological doses of hormones before correlating responses to exogenous hormones with normal physiological events.

\section{Pregnancy}

\section{Early pregnancy and embryonic death}

Little of the following information is presently available for buffalo or zebu but is of paramount importance for $\mathrm{AI}$ and embryo transfer.

At mating the bull deposits semen in the anterior vagina. Penetration of gametes into the cervix may depend on muscular actitivy in the female tract but entry into the uterus is also dependent on sperm motility. The condition of the cervical mucus is critical; the cervix provides the main 
post-coital reservoir in ruminants at least during the first $24 \mathrm{~h}$; another important storage site for up to $48 \mathrm{~h}$ occurs in the lower isthmus and the utero-tubular junction where spermatozoa are protected from phagocytosis. Distribution of spermatozoa in the isthmus of the oviduct is very uniform by $8 \mathrm{~h}$ after mating but muscular activity has clustered the spermatozoa by $18 \mathrm{~h}$. Even though spermatozoa have been found in the oviducts within 2-4 min after deposition of semen in the cervix in buffaloes and cows (Bhattacharya, 1974), the important factor is the arrival of spermatozoa capable of fertilization within the location of the egg (Hunter, 1980; for review). Spermatozoa require at least $4-5 \mathrm{~h}$ in the female tract to complete the process of capacitation before successful fertilization can take place. The greatest percentage fertility is obtained after AI between midoestrus and $6 \mathrm{~h}$ after the end of oestrus which is equivalent to the period $24-7 \mathrm{~h}$ before ovulation. Only a small fraction of the ejaculate reaches the upper oviduct at time of fertilization. The probability of post-ovulatory ageing of the egg before sperm penetration is very low with natural mating but if $\mathrm{AI}$ is employed the female gamete may undergo deterioration before fertilization. It takes only $6-8 \mathrm{~h}$ after ovulation for the egg to become unfertilizable.

Fertilization rate in cow heifers is high (74-98\%; Kidder, Black, Wiltbank, Ulberg \& Casida, 1954) but fertilization wastage rates in cows for bulls not selected for high fertility is in the region of $15-19 \%$. In repeat breeder cows fertilization wastage rates can be as high as $30-40 \%$ (Ayalon, 1978). Data on fertilization rates in buffalo and zebu by natural service or by AI are meagre. There has been a suggestion that low fertilization rates occur in Brahman cattle (Plasse, Warnick \& Koger, 1970) although this may simply reflect embryo recovery technique (Elsden \& Kessler, 1983).

The 8-16-cell cow embryo enters the uterus about $96 \mathrm{~h}$ after ovulation. Alteration in the hormonal status of cows at this time interferes with tubal transport and may lead to reduced fertility. Differentiation of the conceptus into embryonic and placental elements occurs by the 8 th day, when the zona pellucida is shed (Fig. 2).

Elongation of the blastocyst begins at Days 12-13 and its length increases rapidly during the next few days. A viable blastocyst must be in the uterus on Day 16 to inhibit luteolysis (Betteridge, Eaglesome, Randall \& Mitchell, 1980). However, interaction between the blastocyst and the maternal system occurs before this stage (Fig. 2).

Classical morphological evidence in the cow suggested that attachment did not begin until after Day 30 (Winters, Green \& Comstock, 1942) when chorionic (trophoblastic) villi make contact with specific maternal tissues in the crypts of the caruncles. However, ultrastructural studies have shown that the first phase of adhesion of the cow embryo has begun by the 19th day. Placentation in the cow involves apposition, adhesion and attachment in the intercaruncular and caruncular regions at about the same time (King, Atkinson \& Robertson, 1982) and, although distinctive placentomes are formed, the placenta is diffuse for at least the first month after attachment. Apposition begins near the embryo and spreads to the tips of the chorionic vesicle, but it is not possible to designate specific times for events with absolute certainty. The trophoblast binucleate cells may produce a chorionic gonadotrophin, may be involved in the establishment of a syncytium between maternal and fetal components for immunological protection, or may have a role in the transportation of placental lactogen.

In a study of early embryonic death in cows after AI, Roche, Boland \& McGeady (1981) summarized the available literature and proposed a gradual loss of embryos between Days 8 and 18. This includes an average wastage of $15 \%$ due to the failure of fertilization increasing to $35 \%$ by embryonic death by Day 18 (Fig. 2). In repeat breeder cows earlier losses occur with a wastage rate of $42 \%$ by Days 6-7 soon after the normal embryo has entered the uterus (Ayalon, 1978).

Linares, Larson \& Edqvist (1982) studied cow embryos on Day 7 and found abnormal embryonic development with concurrent normal luteal function as assessed by peripheral plasma progesterone values. The proportion of cows in which embryonic death occurs before Day 35 is believed to be much higher in the tropics than it is in more temperate zones (Stott \& Williams, 1962). The causes of early embryonic loss may involve altered uterine biochemistry (Ayalon, 1978), possibly brought about by hormonal imbalances (Flint, 1984). 
Entry of egg into oviduct

Fertilization

2- and 4-cell stage

Entry of 8-cell embryo into uterus

Morula stage

Usual time for embryo transfer

$8 \quad$ Blastocyst stage

Zona pellucida fragments

13 Elongation

15 Blastocyst steroid production

Placental lactogen production

Last day for successful embryo transfer

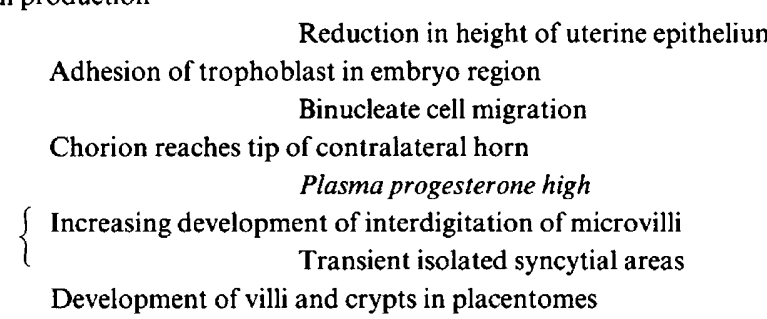

Oestrone sulphate measurable in allantoic fluid

Endometrial epithelium regenerating

$5 \%$

Fig. 2. Approximate times for the stages of development and embryonic losses in early pregnancy of the cow.

Based on progesterone measurements, Ball (1978) estimated a further $10 \%$ embryo loss between Days 28 and 43 . Only a smail percentage of prenatal loss occurs after Day 40 , i.e. about $5 \%$ according to Fosgate \& Smith (1954). However, under conditions of spontaneous or induced twinning in which two sets of fetal membranes were located largely in one uterine horn, a more significant level of later embryonic loss may be found.

Little data on reproductive wastage rates in buffaloes and zebu are available.

\section{Length of pregnancy}

The gestation period of buffalo is between 310 and 330 days; Murrah buffalo have an average length of 315 days compared to 330 days in swamp buffalo (Mason, 1974). Zebu have a 292-day pregnancy (Plasse, Warnick \& Koger, 1968c). Cows have a shorter gestation length of about 285 days; for each species there are, however, documented breed differences. This is important when considering the correct timing for induction of parturition (see later).

Interesting studies have been carried out using embryo transfer to produce cow-zebu twin calves by transferring Day 6-8 zebu or cow embryos to previously inseminated cow or zebu dams (Summers, Shelton \& Edwards, 1983). There were substantial losses (33\%) after 7-8 weeks of pregnancy which may reflect an adverse immunological reaction due to genetic disparity and facilitated by common blood circulations when the bovine fetus becomes immunocompetent. In 
addition the cow fetuses were capable of initiating parturition around 284 days even when in the contralateral horn to the corpus luteum in zebu dams, which usually have a gestation length of about 292 days. This emphasizes a major systemic component to the luteolytic mechanisms of the bovine fetus at term. There was no evidence that the rates of growth and maturation of zebu calves were enhanced by vascular conjunction with faster growing and earlier maturing cow calves: the cow calves presumably initiated parturition in spite of the immaturity of the zebu calves. Bovine twins of disparate durations of gestation may constitute an experimental model to separate physiological maturation of the fetus from the initiation of parturition.

During the first two-thirds of pregnancy in each species the rate of growth of the placenta exceeds that of the fetus; during the last third the situation is reversed-this is when nutritional stresses affecting the birth weight and survival are important. The weight of fetal membranes and oestrogen production are proportional to the size of the calf (Bhattacharya, 1974; Osinga \& Hazeleger, 1979).

The total number of placentomes in the pregnant zebu uterus is about 69 (Stickland \& Purton, 1977), significantly lower than the figures of 70-142 quoted for the cow. This reduction may reflect the often poor nutritional status of the zebu as has been shown for the ewe (Everitt, 1968) and in turn may be responsible for the poor calf survival rates in this species (Turner, 1980).

\section{Endocrinology}

Progesterone. In early pregnancy the plasma concentration of progesterone is maintained at luteal-phase values suggesting maintenance of the corpus luteum (river buffaloes: Batra et al., 1979; swamp buffaloes: Kamonpatana et al., 1979b; cows: Bulman \& Lamming, 1978; zebu: Shelton \& Summers, 1983). El-Sheikh, Sakla \& Amin (1969) reported increasing progesterone content in the buffalo corpus luteum until about Day 13 of pregnancy, as Melampy, Hearn \& Rakes (1959) had found in the cow. Peripheral plasma PGFM does not increase around Day 18-20 if the buffalo (Batra \& Pandy, 1983a) or cow (Kindahl et al., 1976) is pregnant. As well as altering prostaglandin release, the embryo stimulates a luteotrophic effect possibly by its own steroid-synthesizing ability and/or by producing a protein which maintains luteal progesterone synthesis (Hansel, 1981).

Nancarrow, Wallace \& Grewal (1981) have shown, by a rosette-inhibition test, the presence of an early pregnancy factor in the blood of cows 4 days after insemination. Development of such a technique for pregnancy diagnosis might be very useful (Shaw \& Morton, 1980).

Measurements during mid-pregnancy are sparse. There is very little change in plasma LH (average $0.5 \mathrm{ng} / \mathrm{ml}$ ) and progesterone (average $1.5 \mathrm{ng} / \mathrm{ml}$ ) throughout the whole of pregnancy in swamp buffaloes (Kamonpatana, 1984) as in cows (Schams, Hoffman, Fischer, Merz \& Karg, 1972) and zebu (Shelton \& Summers, 1983) although average progesterone values are higher $(6.0 \mathrm{ng} / \mathrm{ml})$ in pregnant cows and zebu than in buffaloes (Fig. 3). It is not clear whether the placenta produces significant amounts of progesterone in mid-pregnancy. Amin \& El-Sheikh (1973) measured progesterone in placental tissue obtained from river-type buffaloes: values were very low in early pregnancy with increases between Days 97 and 250. The same has been observed in cows (Melampy et al., 1959) although some authors (MacDonald, McNutt \& Nichols, 1953; Zimbelman, Loy \& Casida, 1961; Ainsworth \& Ryan, 1967) claim that negligible amounts of progestagens are synthesized by the bovine placenta. The corpus luteum of pregnancy produces large amounts of progesterone throughout the whole of pregnancy but a contribution by the placenta or the adrenals (Wendorf, Lawyer \& First, 1983) cannot be overlooked as this may be the reason why administration of prostaglandin alone is unsuccessful in terminating pregnancy in cows from Days 120 to 250 after insemination (see later).

Oestrogen. Oestrogens are definitely synthesized by the placenta (Ainsworth \& Ryan, 1966). Concentrations of oestrone sulphate increase in maternal peripheral blood from about Day 150 of pregnancy in buffaloes (Kamonpatana, 1984) and Day 100 in cows (Robertson \& King, 1979). The 

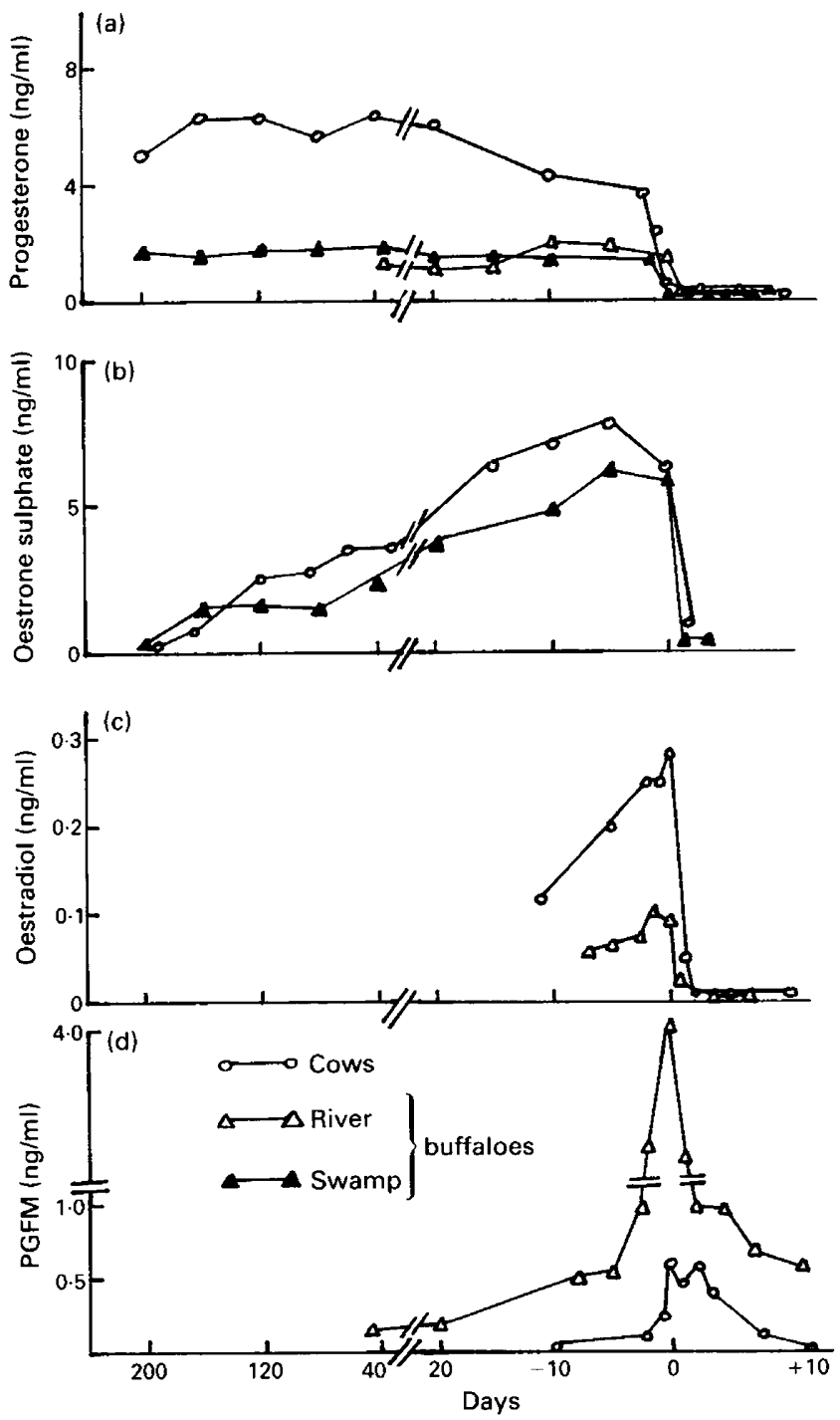

Fig. 3. Peripheral plasma concentrations of (a) progesterone, (b) oestrone sulphate, (c) oestradiol, and (d) PGFM during pregnancy of river $(\Delta)$ and swamp $(\boldsymbol{\Delta})$ buffaloes, and of cows (O). Data for river buffalo after Batra et al. (1982); for swamp buffalo after Kamonpatana (1984); and for cows after Dobson \& Dean (1974), Robertson (1974), Robertson \& King (1979), Thatcher et al. (1980) and Kaker et al. (1984).

temporal discrepancy with placental progestagen synthesis may be due to different sources of material, i.e. direct tissue synthesis may be detectable earlier than increased peripheral plasma concentrations. Nearer the end of pregnancy the placenta appears to switch solely to oestrogen synthesis. This is documented for cows (Evans \& Wagner, 1981) but only recorded as peripheral hormone values in zebu (Shelton \& Summers, 1983) and buffaloes (Perera, Abeygunawardena, (Thamotharam, Kindahl \& Edqvist, 1981; Batra et al., 1982; Kamonpatana, 1984). Circumstantial evidence is provided for buffalo in the $2-4$-h period between fetal and placental expulsion when oestrogen concentrations remain elevated but decline immediately after placental expulsion (Kamonpatana, 1984). Such evidence is not available for cows or zebu. 


\section{Temporal relationships around parturition}

Peripheral plasma progesterone concentrations remain at about $2 \mathrm{ng} / \mathrm{ml}$ until 1 week pre partum in swamp and river buffaloes; values then decline slowly until 1 or 2 days before birth (Fig. 3a). A precipitous further decline to $0.4 \mathrm{ng} / \mathrm{ml}$ occurring $16-30 \mathrm{~h}$ before parturition has been recorded in blood samples taken every few hours. A similar temporal pattern has been found for cows (Schams et al., 1972; Hunter, Fairclough, Peterson \& Welch, 1977; Kaker, Murray \& Dobson, 1984). Increases in placental oestrogen synthesis occur in buffaloes, cows and zebu over the last 5-10 days. In each study on buffaloes a different oestrogen has been measured but in cows temporal changes of each oestrogen are similar to those in buffaloes (Fig. 3b, c).

In the cow fetal cortisol concentrations slightly precede but parallel the increase in oestrogen concentrations (Hunter et al., 1977), suggesting that increased fetal cortisol plays a role in the initiation of parturition in cows as in other species. Definite evidence has not yet been provided for buffaloes and zebu but maternal plasma cortisol values are higher before parturition in swamp buffaloes (Kamponpatana, 1984), increasing from $\sim 2.0 \mathrm{ng} / \mathrm{ml}$ on Day -20 to $4.2 \mathrm{ng} / \mathrm{ml}$ on Day 0 .

Oestradiol values in buffaloes increase with increasing PGFM values (Batra et al., 1982). The latter begin to increase about 10 days pre partum from 0.5 to $4.0 \mathrm{ng} / \mathrm{ml}$ at parturition; lower values have been reported for cows, $0.1 \mathrm{ng} / \mathrm{ml}$ increasing up to $0.6-0.8 \mathrm{ng} / \mathrm{ml}$ (Fig. 3d; Edqvist, Lindell \& Kindahl, 1981; Kaker et al., 1984). Over the last 7 days of pregnancy PGFM values are negatively correlated with progesterone values; the former may cause the luteolysis to decrease progesterone values and hence remove the block on uterine myometrial activity, leading eventually to birth. PGFM values are raised further for 3-4 days after parturition in the buffalo and cow, and baseline values of $0 \cdot 1 \mathrm{ng} / \mathrm{ml}$ are not attained until 10-20 days after calving.

During the last week of pregnancy in cows the concentration of oestradiol and PGF-2 $\alpha$ is higher in the mammary gland vein than in arterial blood (Maule Walker, Davis \& Fleet, 1983). The secretion of oestradiol may be the product of mammary lysis of conjugated steroid rather than endogenous synthesis. These hormonal changes occur immediately before the onset of copious milk secretion.

A two-fold increase of prolactin concentration from 200 to $400 \mathrm{ng} / \mathrm{ml}$ occurs 1 day before parturition in buffaloes (Batra et al., 1982; Kamonpatana, 1984) whereas in cows a 3-5-fold increase has been reported (Hoffman et al., 1973; Thatcher et al., 1980). However, when prolactin concentrations were suppressed by bromocriptine administration (Hoffman et al., 1973) parturition occurred normally in cows. The role of prolactin in the initiation of lactation is not disputed. Measurements in zebu are not available.

Oxytocin concentrations in cows increase sharply from $<3 \mathrm{pg} / \mathrm{ml}$ before parturition to $65-150 \mathrm{pg} / \mathrm{ml}$ when the calf passes through the cervix. High values are maintained for about $2 \mathrm{~h}$, with lower values of $10 \mathrm{pg} / \mathrm{ml}$ until the placenta is expelled (Schams \& Prokopp, 1979). High values during the expulsive phase are in keeping with the Ferguson concept that release of oxytocin is induced by stretching of the birth canal. This must be borne in mind when investigating precise temporal relationships of PGFM values with stages of labour since vaginal examination to record stage of labour will itself release oxytocin and prostaglandins (Flint, Anderson, Patten \& Turnbull, 1974).

First-stage labour in cows and buffaloes lasts $2-6 \mathrm{~h}$. The period of delivery is about $30-40 \mathrm{~min}$ and the placenta is normally shed $2-6 \mathrm{~h}$ after birth.

\section{Pharmacological termination of pregnancy}

No data are available concerning the induction of abortion or parturition in buffaloes and zebu, either as a management aid or as a technique to obtain a greater understanding of the control of parturition.

It is possible to initiate abortion in cows by administration of PGF- $2 \alpha$ (or analogues) up to 
about Day 120 of pregnancy, thereafter it is unreliable (Schultz \& Copeland, 1981). From about Day 250 PGF- $2 \alpha$ alone is again effective, with delivery occurring $26-48 \mathrm{~h}$ after treatment (Johnson, 1981). The mechanism of action is by luteolysis rather than the uterine contractile properties of PGF- $2 \alpha$ and a small amount of progestagen production by the placenta between Days 120 and 250 might reduce the efficacy of luteolysis to initiate parturition.

Exogenous glucocorticoids mimic fetal cortisol by altering the placental steroid synthesis at parturition (Wagner, 1980). Long- and short-acting analogues are available; the former being used between Days 120 and 250 and the latter between Days 250 and 280. Placental retention is lower after the use of long-acting corticoids. Combination treatments of long-acting corticoid followed by a short-acting corticoid analogue 7-10 days later result in more precise synchronization, and better calf survival. The nearer to the end of the pregnancy that these agents are given, singly or in combination, the sooner after treatment will calving occur, and the greater are the chances of calf survival. It is therefore important to appreciate breed differences in normal gestation lengths. For clinical purposes, one problem with corticoid treatment alone is that a live fetus is essential for successful termination of pregnancy; with prostaglandin treatment termination occurs whether the fetus is dead or alive.

Combination treatments of glucocorticoid and PGF- $2 \alpha$ terminate pregnancy irrespective of time in pregnancy. Glucocorticoid injection can be followed 10 days later by a PGF-2 $\alpha$ analogue (Murray, Nutter, Wilman \& Harker, 1982) or both agents can be used at the same time (Mapletoft, Lewing \& Wilson, 1984).

The maternal endogenous hormone profiles are very similar to those around normal parturition (Hoffman et al., 1973; Kaker et al., 1984).

\section{The inter-calving period}

One of the physiological differences between buffaloes, cows and zebu concerns the length of the inter-calving period and this obviously has major economic implications. In the U.K. the recorded interval averages 375-380 days for dairy cows (R. E. Esslemont \& H. Boyd, personal communication), and 381 days for suckler herds (A. R. Peters, personal communication) are in stark contrast to 391-570 days for buffaloes (El-Wishy \& El-Sawaf, 1971; Ahmed, Chaudry \& Khan, 1981; Lundström et al., 1982) and zebu (Luktuke \& Subramanian, 1961). This difference may be attributed to management practices but it is worth considering: (a) the post-partum period, during which equilibrium is regained after pregnancy and calving in order to come into oestrus; and (b) the period from first oestrus to conception. Both these periods involve interrelationships between hypothalamus, pituitary, ovaries and uterus.

\section{Uterus}

The size of the uterus decreases markedly over the first 14 days post partum, associated with a concomitant lochial discharge. The involuting uterus approaches its former non-pregnant size by 28 days post partum in suckling swamp buffaloes (Jainudeen et al., 1982) but nearer 45 days in hand-milked river buffaloes (Roy \& Luktuke, 1962; El-Fouly, Kotby \& El-Sobhy, 1976b). There are similar figures of 2547 days for dairy cows, and 37-56 days for suckling beef cows (Morrow, Roberts \& McEntee, 1966). Involution of the cervix parallels uterine involution but it contracts more slowly in the presence of the retained fetal membranes.

After calving the uterus secretes PGF-2 $\alpha$. In cows the post-partum decline in PGFM values is correlated with uterine horn diameter (Eley et al., 1981). Kindahl, Frederiksson, Madej \& Edqvist (1984) suggest that cows with the longest duration of increased PG release also undergo the most rapid uterine involution. 
Prostaglandin release occurs at the same time as degeneration of decidual cells (0-10 days post partum) and regeneration of the caruncular epithelium (complete by about 21 days post partum). Edqvist, Lindell \& Kindahl (1981) measured little PGFM after abortion induced before 100 days of pregnancy, compared to the large amounts after premature parturition later in pregnancy. The amount of PGFM released possibly reflects the amount of uterine repair which is required.

Uterine or cervical involution are not contributory to the low post-partum reproductive efficiency of buffaloes and zebu (although endometritis might be important; see later).

\section{Ovaries and oestrus}

The onset of ovarian activity during the post-partum period has been studied by ovarian palpation per rectum, expression of oestrus, and milk or plasma hormone values. Ovarian palpation shows that buffaloes have a delayed start to the resumption of ovarian activity, with an average calving-to-first-ovulation interval of $51.6 \pm 2.1$ days in river buffaloes (El-Fouly, Kotby \& El-Sobhy, 1976c) although a value of $37 \cdot 7 \pm 2 \cdot 0$ days has been obtained for Murrah-Nili Ravi buffaloes (Singh, Chauhan \& Singh, 1979b). This compares to $19.4 \pm 3.3$ days in dairy cows (Carruthers \& Hafs, 1980). These differences in onset of ovarian activity are further reflected in the later expression of first oestrus at $77.9 \pm 4.1$ days in milked buffaloes, compared to 20.4 days in dairy cows (Morrow et al., 1966), 52.2-80.2 days in beef cows (Morrow, Roberts \& McEntee, 1969), and 84.6 days in zebu (Luktuke $\&$ Subramanian, 1961). The incidence of silent oestrus is high in the early post-partum period: $77 \%$ at the first post-partum ovulation, with $54 \%$ and $36 \%$ at the second and third ovulations respectively. The frequency of silent oestrus is related to post-partum oestrus number rather than to the length of the post-partum interval (Morrow et al., 1966).

As natural mating systems are currently retained for use in many buffalo and zebu herds it must be assumed that detection of oestrus is as efficient as possible, but problems occur as soon as humans are involved, as often happens with increased use of AI. Even with the use of bulls for detection of oestrus there are problems concerning the return to ovarian cyclicity and expression of oestrus.

Undoubtedly, management practices contribute to the problem; for example buffalo calves are widely suckled mainly to reduce calf mortality. Suckling for 60 days post partum increases the interval to onset of ovarian activity to $87.0 \pm 2.5$ days and of first heat to $131.5 \pm 4.9$ days (El-Fouly et al., 1976c). In cows there is only prolongation of about 19 days to first ovulation (Carruthers \& Hafs, 1980), hence suckling appears to have a greater effect on buffaloes and zebu (Wells, Holness, Freymark, McCabe \& Lishman, 1985) than on cows.

The effect of season has a very marked effect on inter-calving intervals, buffaloes calving in the cooler winter months have shorter intervals from calving to first oestrus (Ahmed et al., 1981; Lundström et al., 1982). Similarly, well-nourished Brahman zebu calving at the beginning of the breeding season can have intervals of only 65 days (Plasse, Koger \& Warnick, 1968a).

Another factor, possibly associated with environmental temperatures, concerns nutrition. There are few reports concerning the direct influence of nutrition on fertility in buffaloes, but an effect is indicated in the report by Bhalaru, Dhillon \& Tiwana (1981) on weight losses. These losses continued for 120-150 days after calving (compared to only 60 days in cows: Youdan \& King, 1977 ) with buffaloes weighing $>550 \mathrm{~kg}$ losing a greater percentage of body weight $(7.65 \%)$ than those weighing $<475 \mathrm{~kg}$ which lost only $1 \cdot 13 \%$. The conception rate to first service was $10-20 \%$ lower in buffaloes losing more weight and consequently the calving-to-conception interval was 20-30 days longer than in controls (139 days compared to 110-121 days). In a study of suckling swamp buffaloes, Jainudeen et al. (1982) revealed weight losses of about 7\% over the period 70-140 days post partum. Only 20 out of 38 buffaloes displayed evidence of resumption of ovarian cyclicity during this period. 


\section{Endocrinology}

Peripheral plasma concentrations of oestradiol and progesterone decline from high values during late pregnancy to very low values over the first 4 or 5 days after parturition (Batra et al., 1982; Kaker et al., 1984). There is a suggestion from Pahwa \& Pandey (1983) that progesterone values in some buffaloes do not reach baseline $(0.05-0.08 \mathrm{ng} / \mathrm{ml})$ until as late as 29 days post partum, in agreement with Singh et al. (1979b) who reported that the corpus luteum of pregnancy is still palpable from 2 to 45 days post partum. In cows there is no evidence to substantiate this claim that the CL of pregnancy is endocrinologically active so late in the post-partum period, and a study of swamp buffalo (Jainudeen et al., 1982) gives no support either.

Prolactin concentrations appear to stabilize by $2-5$ days post partum in buffaloes at $200 \mathrm{ng} / \mathrm{ml}$ (Batra et al., 1982) and in cows at $12 \mathrm{ng} / \mathrm{ml}$ (Webb, Lamming, Haynes \& Foxcroft, 1980). The differences in concentration may relate to assay methodology, or to climate because daylength and ambient temperature are important in regulating prolactin release (Koprowski \& Tucker, 1973). High prolactin concentrations, however, are not thought to be antigonadotrophic (Williams \& Ray, 1980) or to be the cause of prolonged post-partum anoestrus in cows (Webb et al., 1980).

Peripheral plasma concentrations of LH in buffaloes are higher on Day 21 than at calving, ranging between 0.22 and $0.78 \mathrm{ng} / \mathrm{ml}$. Baseline values of $\mathrm{LH}$ during the $2 \mathrm{nd}$ and $3 \mathrm{rd}$ week post partum are inversely related to the interval to the first post-partum ovulation (Batra \& Pandey, 1983b). In dairy cows there is gradual increase in tonic LH values from almost undetectable levels at calving to $1.0 \mathrm{ng} / \mathrm{ml}$ around Day 10 post partum (Webb et al., 1980); this may be directly related to the removal of the high progesterone and oestradiol values which occurred during pregnancy. An increase in pituitary LH concentration also occurs from parturition until 20-30 days post partum (Wagner, Saatman \& Hansel, 1969). In addition, in dairy cows there is an increased pituitary response in terms of $\mathrm{LH}$ release to exogenous $\mathrm{GnRH}$ over the period $0-10$ days post partum (Lamming, 1978). Similar studies in suckling swamp buffaloes (Jainudeen, 1984) indicate that pituitary responsiveness to $\mathrm{GnRH}$ is restored by Day 30 post partum, but this alone would not account for the very prolonged post-partum interval. In suckling cows there-is a delay in the appearance of LH episodes so suckling may delay the first post-partum ovulation by suppressing pulsatile LH secretion (Carruthers \& Hafs, 1980).

After Day 10 post partum in dairy cows, the tonic episodic release of LH in cows is interspersed with preovulatory LH surges. There is an increase in the baseline concentration from 6 days before an LH surge, decreasing to baseline immediately afterwards (Webb et al., 1980). Such increases occur in cows between Days 12 and 29; this work has not yet been carried out in buffaloes or zebu.

There appears to be no consistent pattern of plasma FSH concentrations in the post-partum period of dairy cows (Dobson, 1978b; Schams et al., 1978; Webb et al., 1980) and it is thought that changes in plasma FSH are not critical for the initiation of the first ovarian cycle.

Plasma concentrations of oestradiol in milked Murrah buffalo increase from low post-partum values of $10-15 \mathrm{pg} / \mathrm{ml}$ to values of $20-25 \mathrm{pg} / \mathrm{ml}$ at oestrus, during the period 23-177 days post partum. Measurements in post-partum dairy cows reveal low values of $1-3 \mathrm{pg} / \mathrm{ml}$ increasing to 6-10 pg/ml around Days 10-15 (Abeywardene, Hathorn \& Glencross, 1984; Kaker et al., 1984). This rise in oestradiol values is coincident with early follicular growth about this time, although oestrus is usually not observed. Similar concentrations of oestradiol are found during the later oestrous cycles, when behavioural symptoms of oestrus occur.

Low values of progesterone in plasma or milk are maintained for variable lengths of time post partum until the resumption of ovarian cyclicity. Following the first post-partum ovulation, plasma progesterone values rise to $0.7 \mathrm{ng} / \mathrm{ml}$ or above for at least 10 days, then decline before the next oestrus (Webb et al., 1980). Truly anoestrous buffaloes are easily identified by plasma progesterone values $<0.5 \mathrm{ng} / \mathrm{ml}$ on repeated sampling at 3-4-day intervals. Fluctuations in plasma progesterone concentrations closely correlate with luteal morphology and function (Jainudeen, Sharifuddin \& Bashir Ahmed, 1983) although a comparison of laparoscopic methods, ovarian palpation per 
rectum, and hormonal diagnosis of a corpus luteum indicated that, in swamp buffaloes, follicles $>10 \mathrm{~mm}$ diameter had a tendency to bulge from the ovarian surface, making it difficult to differentiate a corpus luteum from a follicle per rectum between 30 and 150 days post partum (Sharifuddin \& Jainudeen, 1983).

The first post-partum ovulation based on plasma progesterone occurs from $96 \pm 22$ days in swamp buffaloes (Jainudeen et al., 1982) and beyond 60-90 days in river buffaloes (Perera et al., 1981). About $25-30 \%$ of oestrous periods associated with the first post-partum ovulation were not detected even by a vasectomized bull (Jainudeen et al., 1983).

One very interesting paper, albeit about regularly cyclic animals, has important implications for post-partum buffaloes. Plasma progesterone profiles of two groups of buffaloes on two different levels of nutrition revealed long periods of anoestrus in the underfed group, especially during high environmental temperature stresses (Kaur \& Arora, 1984). This may be the basis for the periods of prolonged anoestrus during the post-partum period.

Measurement of post-partum progesterone profiles in dairy cows has revealed quite a different picture. Bulman \& Lamming (1978) showed that $77.5 \%$ dairy cows under U.K. conditions resumed cycles by $24 \pm 0.6$ days after calving. This correlates well with the average time of first follicular growth (15 days) and ovulation (20 days) as detected per rectum by Morrow et al. (1966). In comparison, suckling beef cows resumed ovarian cyclicity by $56.9 \pm 2.5$ days post partum (Peters \& Riley, 1982). Of the dairy cows only $4.9 \%$ had not resumed cyclic ovarian activity within 50 days of parturition; $5 \cdot 1 \%$ began ovarian cycles within the normal time but subsequently ceased to cycle for at least 14 days; $1.9 \%$ had prolonged luteal activity for at least 30 days without insemination; and $10.7 \%$ had two consecutive ovulations (excluding the first post-partum ovulation) unaccompanied by observed oestrous behaviour. Progesterone profiles in post-partum zebu are not yet available.

\section{Fertility}

As in cows the calving-to-conception and calving-to-first-oestrus intervals decrease with increasing parity in buffaloes (El-Wishy \& El-Sawaf, 1971; Singh et al., 1979b). Similarly, milk yields increase with increasing parity. Average lactation lengths in buffaloes range from 340 to 349 days with intercalving periods of 391-570 days, emphasizing the uneconomic breeding efficiency. Early return to ovarian activity, and oestrus, is only beneficial if adequate conception rates can be achieved. This reflects the ability of the ovary to produce a viable egg and the successful attraction of the male, and also the ability of the uterus to maintain a conceptus.

There is an increasing rate of efficiency with increasing time after calving (see Table 2; there are insufficient detailed data available for zebu). Similar patterns and values were obtained in buffaloes and cows with only just over $30 \%$ conceiving after breeding within 20 days of calving to an average

Table 2. Comparison of fertility after calving in buffaloes and cows

\begin{tabular}{|c|c|c|c|c|c|c|c|c|}
\hline \multirow{2}{*}{$\begin{array}{l}\text { Calving to lst } \\
\text { insemination } \\
\text { (days) }\end{array}$} & \multicolumn{2}{|c|}{$\begin{array}{c}\text { Conception rate to } \\
\text { lst service }(\%)\end{array}$} & \multicolumn{2}{|c|}{ Serves/conception } & \multicolumn{2}{|c|}{$\begin{array}{l}\text { Calving-to-conception } \\
\text { interval (days) }\end{array}$} & \multicolumn{2}{|c|}{$\begin{array}{l}\text { First } \\
\text { service-to-conception } \\
\text { interval (days) }\end{array}$} \\
\hline & Buffaloes & Cows* & Buffaloes & Cows* & Buffaloes & Cowst & Buffaloes & Cowst \\
\hline$<30$ & 32 & 35 & $2 \cdot 36$ & $2 \cdot 86$ & 121 & - & 97 & - \\
\hline $31-60$ & 51 & 41 & 1.87 & $2 \cdot 44$ & 116 & 90 & 71 & 47 \\
\hline $61-90$ & 54 & 51 & $1 \cdot 72$ & 1.97 & 127 & 114 & 50 & 38 \\
\hline $91-120$ & 62 & 58 & 1.63 & 1.73 & 146 & 130 & 38 & 19 \\
\hline$>120$ & 70 & $52 \cdot 4$ & $1 \cdot 3$ & 1.91 & 163 & - & 26 & - \\
\hline
\end{tabular}

Buffalo data taken from: El-Wishy, Abdou \& El-Sawaf (1971); Singh et al. (1979b).

Cow data taken from: * VanDemark \& Salisbury (1950); † Esslemont (1982). 
of about $2 \cdot 5$ services per conception. Acceptable efficiency is achieved between 91 and 120 days with first-service conception rates of about $60 \%$ and around 1.68 services per conception. However, it is economically important to achieve low calving-to-conception intervals by breeding as soon as possible after calving, for example, from 50-60 days onwards. Conception rates of $>50 \%$ can be achieved at this time with little deleterious effect on subsequent fertility for those females that do not conceive at first service.

From Table 2 it can be seen that calving-to-conception intervals and first-service-to-conception intervals are longer for buffaloes than cows. These are not due to lower conception rates as these are similar for the two species but more probably are due to the prolonged return to ovarian cyclicity after calving.

\section{Management aids}

One of the major problems confronting the buffalo and zebu farmer and the cowman is the detection of oestrus, but often for distinctly different reasons. Buffaloes and zebu are notorious for overall weak symptoms of oestrus; cows, on the other hand, do mount each other when in oestrus but the cost of labour on Western farms is so high that often sufficient time is not allowed to observe such behaviour. However, three 30-min spells of observation at 06:00, 14:00 and 22:00 $\mathrm{h}$ can achieve detection rates of oestrus of up to $80 \%$ for cows. In addition heat mount detectors such as KaMaRs or Tel-tail paint which are applied to the cow's tail-head have proved useful (Williamson, Morris, Blood \& Cannon, 1972b). However, these latter devices are of little use in buffaloes and zebu due to the absence of homosexual mounting behaviour.

Hormone preparations can be useful to aid detection of oestrus by concentrating the period of observation, or even allowing the use of fixed-time insemination (usually AI); the added advantage, particularly for large herds, is that synchronized mating and hence batch-calving can be contemplated. There is no system yet available to control the time of ovulation very precisely, mainly due to variations in the timing of follicular growth.

\section{Hormone preparations}

To date most reports on buffaloes and zebu have not included the large number of animals required for valid statistical analysis; however, it will probably be only a matter of time. As there are many factors which may influence detection of oestrus and fertility on farms (large or small) great care must be taken to consider any results alongside control untreated animals under identical conditions.

Methods for detection of oestrus are usually those pertinent to the management system involved, which is acceptable for applied research, but it may be prudent in early research stages to use vasectomized, or even intact bulls, to assess the full potential of any system. This is particularly true for buffalo and zebu for which AI procedures are still being developed.

Prostaglandins (PGs). Fertility is the same after the use of preparations of PGF-2 $\alpha$, or synthetic analogues. Only animals with a corpus luteum present at the time of treatment will respond, hence ovarian palpation is necessary. Unfortunately there is no response before Day 5 of the oestrous cycle and so a regimen of two injections 11 days apart has been devised to allow all animals to respond after the second injection (Cooper, 1974). It is also possible to inseminate all animals that respond to the first injection and only reinject those not in oestrus after the first injection.

Early work using the double injections 11 days apart resulted in a good response with oestrus 72-96 $\mathrm{h}$ after the second injection in buffaloes (Perera, Pathiraja, Kumaratilake, Abeyratne \& Buvanendran, 1977; Rao \& Rao, 1978), and zebu (Adeyemo, Akpokodje \& Odili, 1979; Nagaratnam, Sooriyamoorthy, Oyedipe \& Zakari, 1983). First-service conception rates at the induced 
oestrus ranged from 30 to $53 \%$. Later studies with buffaloes (Pathiraja, Abeyratne, Perera \& Buvanendran, 1979) emphasized the importance of correct detection of oestrus, AI technique, and adequate nutrition. Buffaloes treated during the breeding season are more fertile than those treated for suboestrus with first-service conception rates of $51-52 \%$, and $25-44 \%$ respectively (Rao \& Rao, 1979a; Singh, Dugweka, Sharma, Chauhan \& Singh, 1979a). However, rates as high as $53.8 \%$ have been achieved after treatment of suboestrous buffaloes (H. C. Pant \& G. D. Singh, personal communication). Reproductive efficiency after the use of PGs often reflects management situations; Chauhan, Sharma \& Singh (1982) achieved $62.5 \%$ first-service conception rate with suboestrous buffaloes on small village farms, compared to $26.9 \%$ on large farms which were possibly not so well managed.

Plasma progesterone concentrations decline within $24 \mathrm{~h}$ after PG administration, in buffaloes (Chauhan et al., 1982) and cows (Dobson, Cooper \& Furr, 1975). In field conditions only 55-72\% buffaloes and zebu displayed oestrous symptoms after PG treatment (compared to $80-90 \%$ in dairy cows); this may be due to the extra difficulties of initial luteal recognition per rectum because progesterone concentrations at the time of PG injection have been as low as $0.6 \mathrm{ng} / \mathrm{ml}$ (Chauhan et al., 1982; Orihuela, Galina, Escobar \& Riquelme, 1983).

There have been fewer reports on the use of PGs in swamp buffaloes but results are similar to those obtained from the river-type (Jainudeen, 1976; Kamonpatana, Kunawongkvit, Bodhipaksha \& Luvira, 1979a).

In cows ovulation does not take place before $72 \mathrm{~h}$ after $\mathrm{PG}$ administration but $95 \%$ have ovulated by $96 \mathrm{~h}$ (Roche, 1977). Calving rates of $50-53 \%$ occur after fixed-time AI compared to $66 \%$ after AI at observed oestrus (Roche, 1977).

An obvious advantage to the use of PGs is in increased farmer awareness to observe for oestrus over a few restricted days, so that the number of animals served over a given time period is greatly increased. For example, only $10 \%$ of a control group of buffaloes were served during a 21-day period compared to $100 \%$ of a PG-treated group in the 4 days after a second PG injection (Rao \& Rao, 1979a). In addition, if detection of oestrus is poor, attempts can be made to reduce calving-to-conception intervals; in a U.K. diary herd this interval was reduced by 12.5 days using synchronization (Esslemont, Eddy \& Ellis, 1977).

Progestagens. The major disadvantage of the need for an active corpus luteum when using PGs can be overcome by the use of progestagens. Progesterone itself has a short half-life which makes repeated or continuous application essential. Repeated injections are not very practical.

Oral administration of analogues is also of restricted use due to difficulties in regulating the amount ingested by individual animals, although success has been reported for zebu (Jöchle, 1975; Pant \& Sharma, 1979).

Intravaginal sponges have not been used in cattle as extensively as the progesterone-releasing intravaginal device (PRID) or an alternative continuous release formulation, the ear implant, containing potent progestagen (SC 21009; Norgestomet). At the time of implant insertion $3 \mathrm{mg}$ Norgestomet and $5 \mathrm{mg}$ oestradiol benzoate are also injected to induce luteolysis in cattle which are in the early or late stages of the oestrous cycle. This latter regimen is sometimes referred to as Synchromate-B. PRIDs and implants are removed after 9-14 days, to cause a timed decline in circulating progestagen concentrations. Fertility is reduced if progestagens are administered for longer than 14 days.

$P R I D$. The retention rates of these devices are high $(80-100 \%)$ in buffaloes and cows. About $24 \mathrm{~h}$ after insertion maximum peripheral plasma progesterone values are achieved similar to those occurring in the luteal phase (buffalo: Rajamahendran \& Thamotharan, 1983; cows: Roche \& Gosling, 1977). Oestrous symptoms occur in 80-90\% animals after PRID withdrawal (buffalo: Rao \& Rao, 1983; cows: Roche, Prendville \& Davis, 1977). The onset of oestrus occurred earlier after PRID withdrawal than after prostaglandin injection, but buffaloes take longer to come into oestrus after PRID withdrawal (60-78 h; Rajamahendran \& Thamotharam, 1983) than do dairy cows (most about $48 \mathrm{~h}$ after withdrawal: Roche et al., 1977). Data from zebu are not yet available. For 
each species it is important to establish exactly when ovulation takes place after PRID withdrawal, especially if fixed-time AI is not to be attempted.

A combination treatment (PRID insertion for 7 days with PG given 1 day before PRID withdrawal) results in a high pregnancy rate in suckling beef cows no doubt due to initiation of ovarian activity by the PRID in anoestrous animals, and synchronization of the cyclic cows by PG (Beal, 1983).

Using entire buffalo bulls for heat detection and insemination Rajamhendran, Jayatilaka, Dharmawardena \& Thamotharam (1980) achieved 8 out of 10 pregnancies at the first posttreatment oestrus. Fixed-time insemination at 48 and $72 \mathrm{~h}$ after PRID withdrawal has achieved first service conception rates of $40-46 \%$ in studies on a large number of buffaloes in the breeding season (Rao, 1981; Rao \& Rao, 1983). In large studies on dairy cows, suckling beef cows and heifers, first-service conception rates of $50-56 \%$ have been reported after a single AI at $56 \mathrm{~h}$ after withdrawal, or double AI at 56 and 74 h (Roche et al., 1977; Drew, Gould \& Bulman, 1978).

The fertility of anoestrous or suboestrous animals is lower than that of cyclic animals. A first-service conception rate of $25 \cdot 3 \%$ was obtained after PRID withdrawal and fixed-time insemination in 150 buffaloes (Rao \& Rao, 1983) which is comparable to the $27-37 \%$ reported by Willemse, Nieuwenhuis, Dieleman \& Pieterse (1982) for truly anoestrous dairy cows inseminated 60 and $72 \mathrm{~h}$ after coil withdrawal. An additional benefit to the use of PRIDs is that some truly anoestrous animals will continue to cycle if conception does not occur at the first induced oestrus, thus allowing further opportunities to achieve conception. About $50 \%$ of those not conceiving do continue to cycle; presumably the remaining animals return to the domination by the adverse factors which initially prevented cyclicity.

The use of PRIDs in swamp buffaloes and zebu has not yet been extensively reported.

Norgestomet. It is not possible to make a direct comparison between the use of Norgestomet implants in buffaloes and cows, because the use in buffaloes had included an extra injection of 600 i.u. PMSG at the time of implant withdrawal. There is a very good retention rate of implants $(>95 \%)$, provided they are placed correctly in the middle of the concave side of the ear. There is a 95-98\% oestrus response 25-80 h after implant withdrawal (buffaloes: Rao \& Rao, 1979b; cows: Wishart, Young \& Drew, 1977). First-service conception rates after Norgestomet treatment are lower in buffaloes than in cows although this may be a reflection of general and nutritional status, and AI techniques. Conception rates in buffaloes after fixed-time AI at 48 and $72 \mathrm{~h}$ after implant withdrawal were $43.7 \%$ in the breeding season (compared to $46.6 \%$ in contemporary untreated controls artificially inseminated at observed oestrus). Higher rates of $54-84 \%$ have been obtained in dairy heifers after AI at 48 and $72 \mathrm{~h}$ (Wishart et al., 1977).

The Norgestomet regimen has also been attempted in buffalo heifers and adults not seen in oestrus for at least 3 months previously (Rao \& Sreemannarayana, 1983). Artificial insemination $12 \mathrm{~h}$ after observed oestrus immediately following treatment resulted in a first-service conception rate of $15 \%$ in heifers and $36 \%$ in adults. Some animals showed very weak signs of oestrus and their conception rate was as low as $11 \%$. However, many of the non-pregnant buffaloes came into oestrus again 20-22 days later and conceived to AI at that time. The overall conception rate after two inseminations was $46.2 \%$ compared to the rate of $43.7 \%$ achieved after one insemination induced at oestrus during the breeding season. The advantage of this regimen can be appreciated especially as only $10 \%$ of the control anoestrous buffaloes displayed oestrus over the same time period. The influence of environment especially nutrition was again highlighted in a study by Singh, Singh, Sharma \& Nanda (1983) in which conception rates to fixed-time AI after Norgestomet + PMSG were $40 \%$ in village herds compared to $61 \%$ for a well-managed herd.

Suboestrous suckling beef cows have been treated with Synchromate-B 28-45 days post partum (Miksch, LeFever, Mukembo, Spitzer \& Wiltbank, 1978). Those cows cycling before treatment had a $68 \%$ first-service conception to fixed-time AI after treatment compared to $60 \%$ for those not seen in oestrus before treatment. The higher conception rates in this study of cows may again reflect nutritional and management status. Kiser, Dunlap, Benyshek \& Mares (1980) studied suckling beef 
cows in marginal body conditions and showed that calf removal for $48 \mathrm{~h}$ beginning at implant removal resulted in an increased number of cows displaying oestrus ( $77 \%$ compared to $23 \%$ ), an increased first-service conception rate ( $46 \%$ compared to $32 \%)$ and an increased overall conception rate when the cows were left with entire bulls for 25 days after implant removal ( $72 \%$ compared to $59 \%$ ). A similar study in buffaloes and zebu would be very useful especially as calves are often traditionally left to suck for long periods of time. Care, however, must be taken to guard against mis-mothering when calves are returned.

$G n R H$. Prophylactic use of large doses of GnRH given to dairy cows on Days 10-23 post partum have reduced the calving-to-conception interval and services per conception (Bosu, 1982). However, in cows that were truly anoestrous up to Day 35 post partum, the use of a PRID gave better results than a single GnRH injection (Ball \& Lamming, 1983), probably due to the fact that GnRH treatment will only result in normal corpus luteum development if a mature follicle is present at the time of injection. Similarly in suckling beef cows large single doses of GnRH did not induce normal oestrous cycles (Webb, Lamming, Haynes, Hafs \& Manns, 1977), but the multiple low-dose injections $(5 \mu \mathrm{g}$ every $2 \mathrm{~h}$ for $48 \mathrm{~h}$ ) resulted in follicular growth, ovulation and normal luteal function (Riley, Peters \& Lamming, 1981). Data on the use of GnRH in anoestrous buffalo and zebu are not available.

GnRH has also been used at the time of $\mathrm{AI}$ in cows to improve conception rates but with doubtful success (Bosu, 1982). Luteal function has been augmented by GnRH administered on Days 11-13 after AI resulting in increased pregnancy rates in dairy cows (Macmillan, Day, Taufa, Gibb \& Pearce, 1985). Neither of these treatments has been reported for buffaloes and zebu.

\section{Conclusions}

Hormonal therapies are available to help farmers overcome the prolonged periods of anoestrus, but it must be emphasized that improved husbandry is just as likely to succeed. As suggested several times above, adequate nutrition is essential for early return to ovarian cyclicity and many of the management aids simply highlight husbandry deficiencies. Early weaning in buffaloes and zebu may be deleterious to health of the calves as well as increasing the overall cost of production, although temporary calf removal might be exploited. Artificial insemination would obviously be advantageous but much greater knowledge is required concerning the timing of events around oestrus in female buffaloes and zebu, as well as the handling of semen, and AI techniques.

Studies have already been carried out on buffaloes and zebu, but often under experimental conditions. This is necessary initially, but the conditions might be very different in the small villages and such field data are very important as this is where a large proportion of buffaloes and zebu are located.

\section{Pregnancy diagnosis}

Any attempts to increase reproductive efficiency rely heavily on early, accurate methods for the diagnosis of pregnancy. Without such methods the inter-calving period can be excessively prolonged, especially in seasonal breeders.

\section{Visual methods}

The occurrence of oestrus about 21 days (or multiples of 21 days) after insemination is a fairly good guide to the failure of the establishment of pregnancy (although a few animals do display oestrus later in pregnancy). This method does, however, rely heavily on efficient detection of oestrus and these non-return rates lead to an overestimation of pregnancy rates of at least $10-20 \%$. 


\section{Observations of the uterus}

Palpation of the uterus per rectum is one of the most common methods of bovine pregnancy diagnosis. Obviously the technique depends on operator expertise, as well as the stage in pregnancy. Distension of the uterus is palpable by 6 weeks after insemination; by 4 months the body of the uterus has fallen beyond the pelvic brim in most animals. There does not appear to be a critical assessment in the literature concerning the technique in buffaloes and zebu, but in one study $94 \%$ cows did eventually calve (Vaillancourt et al., 1979).

Ultrasonic rectal probes to detect fetal circulation have also been investigated in cows but use is restricted to beyond 8 weeks after insemination and accuracy rates rarely exceed $90 \%$. Real-time ultrasonic-scanning is also now being developed.

\section{Progesterone measurements}

In early pregnancy, progesterone concentrations in milk or plasma are maintained at mid-luteal values during Days 18-27, whereas values are very low at this time in non-pregnant animals. Heap, Holdsworth, Gadsby, Laing \& Walters (1976) suggested that Days 21-24 were the most appropriate for sample collection from cows and similar conclusions were reached from studies on buffaloes (Kamonpatana et al., 1979b; Perera, Pathiraja, Abeywardena, Motha \& Abeygunwardena, 1980; Singh \& Puthiyandy, 1980). Data from zebu are not yet available. The accuracy of determining non-pregnancy is much greater $(95-100 \%)$ than that for determining pregnancy (66-80\%) (river buffaloes: Perera et al., 1980; Singh \& Puthiyandy, 1980; cows: Dobson \& Fitzpatrick, 1976). The high fat content of buffalo milk makes consistent sample collection a necessity (Singh \& Puthiyandy, 1980) and for cows, studies on fat-free milk (Pope, Majzlick, Ball \& Leaver, 1976) or on the fat fraction (Hoffman, Gunzler, Hamburger \& Schmidt, 1976) have been attempted to increase the precision of milk progesterone measurements.

Kamonpatana, Chantaraprateep \& Ngramsuriyaroj (1981) have suggested that progesterone measurements may be a useful aid in addition to palpation per rectum to determine which swamp buffaloes are pregnant in a herd without prior knowledge of insemination dates.

The main advantage of the progesterone test is to pick out the non-pregnant animals: this is particularly useful with buffaloes as symptoms of oestrus are so poor. Repeated samples may aid diagnosis of early embryonic death, anoestrus and tract infections, and although no such reports exist yet for buffaloes and zebu, such use has been made in cows. Analysis of milk or plasma has revealed an incidence of mis-timed insemination ranging from 4 to $13 \%$ (Hoffman et al., 1976; Oltner \& Edqvist, 1981). Hoffman et al. (1976) and Dobson, Rankin \& Ward (1977) have suggested that choice of treatments for subfertility would be greatly aided if immediate progesterone measurements were available with the clinical examination.

The development of non-isotopic labelling techniques might allow the possibility of on-farm measurements. Enzyme immunoassays are currently being examined (Kamonpatana et al., 1979b; Arnstadt \& Cleere, 1981; Foulkes, Cookson \& Sauer, 1982) and as very expensive instruments are not required such assays may prove more acceptable in developing countries.

\section{Oestrone sulphate measurements}

Hamon, Fleet, Holdsworth \& Heap (1981) have shown that concentrations of oestrone sulphate in milk increase in the later stages of pregnancy and can successfully be used for confirmation of pregnancy in cows beyond Day 100 . There has been a suggestion that oestrone sulphate measurements may predict the presence of twins although Osinga \& Hazeleger (1979) urge caution as fetal genotype and fetal weight may cause too great a variation. Bolander, Ulberg \& Fellows (1976) have provided convincing evidence that measurements of bovine placental lactogen are more reliable in predicting twins but only after Day 160-200 of pregnancy. 
Plasma oestrone sulphate measurements have also been used to confirm pregnancy in swamp buffaloes (Kamonpatana, Parnpai, Ngramsuriyaroj \& Srisakwattana, 1983b). Such measurements are useful because animals which abort after Day 20 can easily be distinguished.

\section{Clinical aspects of reproduction}

Abattoir surveys are subject to the criticism of possible bias, due to culling for subfertility. However, alarming numbers of pregnant cows and buffaloes at all stages of pregnancy have been found in abattoirs, as high as $25-40 \%$. This suggests that herds may not be managed to best advantage with the culling of valuable breeding animals, perhaps because of inadequate methods of pregnancy diagnosis?

Examination of non-pregnant tracts at the abattoir suggests that there may be more reproductive problems among buffaloes than cows, with reports of only $40-74 \%$ of normal buffalo tracts compared to $85-90 \%$ for cows.

\section{Ovarian abnormalities}

The incidence of totally inactive ovaries in abattoir buffalo tracts ranges from 9 to $23 \%$ (Smith, El-Dessouky, Al-Ansari, Loftah \& Injidi, 1971; El-Wishy, 1979; Samad, Ali, Ahmad \& Najibur-Rehman, 1984) whereas values of $0.32 \%$ and less have been reported for cows (Al-Dahash \& David, 1977; Alam, 1984).

Clinical examinations of live subfertile buffaloes substantiate the abattoir findings; analysis of over 20000 records of referred cases revealed an incidence of $56.36 \%$ ovarian quiescence (Rao \& Sreemannarayana, 1982). In an ovarian palpation study of all buffaloes in a herd up to 45 days post partum, Singh et al. (1979b) reported an incidence of true anoestrus of $17.4 \%$. This compares with a figure of $5.2 \%$ obtained from milk progesterone in cows up to Day 50 post partum (Bulman \& Lamming, 1978). Clinical survey data on zebu from Africa, and from India, have shown that $58-84.8 \%$ of functional reproductive failures are attributed to atrophic ovaries and the absence of ovarian cyclicity (Kumi-diaka, Ogwu \& Osori, 1981; Rao, 1982).

In buffaloes and zebu, ovarian quiescence is more prevalent in hotter summer months and the extent of the problem for the clinician can be appreciated when this is coupled with an overall $6 \%$ 'silent' ovulations, $3.5 \%$ suboestrus, $4 \cdot 3 \%$ anovulatory heats, and $5 \%$ luteal persistency. Also of great significance are the observations that about $25 \%$ of the corpora lutea in river buffaloes and zebu do not protrude sufficiently above the surface of the ovary to allow accurate diagnosis by palpation per rectum (buffalo: El-Wishy, 1979; zebu: Vaca, Galina, Fernandez-Baca, Escobar \& Ramirez, 1983). In a detailed study comparing laparoscopic observations with palpation findings in swamp buffaloes, $81 \%$ of the corpora lutea diagnosed by palpation per rectum were confirmed at laparoscopy (Shariffudin \& Jainudeen, 1983). The overall accuracy of diagnosing ovarian function by plasma progesterone assay was $86 \%$, i.e. not significantly different from palpation accuracy. Very similar values of accuracy, $89 \%$ per rectum and $77-85 \%$ from milk progesterone, have been obtained for cows (Dobson et al., 1977; Watson \& Munro, 1980).

In contrast to cows, buffaloes have a lower incidence of cystic ovarian degeneration (data for zebu are not yet available). Abattoir studies revealed an incidence of $1.8 \%$ for buffaloes compared to $3 \cdot 8-5 \cdot 2 \%$ for cows. The differences are accentuated in live cases presented to veterinarians, i.e. $0.91 \%$ of referred buffalo cases (Rao \& Sreemannarayana, 1982) compared to 8.8-20.0\% of referred cows (Tanabe \& Brofee, 1982). There could be two reasons for the higher incidence of cystic ovaries in cows:

(a) there is a higher incidence earlier in the post-partum period (Morrow et al., 1966) and cows under close veterinary surveillance are more likely to be examined per rectum during this time, and 
(b) stressful situations, such as forcing high milk production in large herds, are more likely to predispose cows to alterations in gonadotrophin secretions caused by excessive adrenal stimulation (Wagner \& Li, 1982).

\section{Endometritis}

The other major pathological difference, found in the abattoir surveys quoted above, concerns uterine lesions, especially (endo)metritis (3.5-24.7\% in buffaloes, compared to $\leqslant 1.0 \%$ in cows). hydrosalphinx $(3.1 \%$ and $<1.0 \%$ respectively) and ovario-bursal adhesions $(10.9 \%$ and $1.8 \%$ respectively). These conditions are often a result of ascending infection. In many Eastern countries it is traditional practice to stimulate the vagina of buffaloes to assist milk let-down. Also, parturition does not often take place in hygienic conditions and human interference is far too frequent, even at normal calvings. These factors, together with extreme heat during the summer months and the wallowing habits of buffaloes, favour infection.

There is a $20-30 \%$ incidence of clinical metritis in live buffalo and zebu cases but non-specific infections of other parts of the tract are restricted to $<1.0 \%$; a lower incidence probably because such lesions are not easily palpated per rectum (buffalo: Rao \& Sreemannarayana, 1982; zebu: Kumi-diaka et al., 1981; Rao, 1982).

As in the cow several micro-organisms are present in the post-partum uterus of the buffalo but many disappear as uterine involution progresses. Organisms frequently isolated from uteri of subfertile buffaloes and cows include Bacillus mycoides, Corynebacterium pyogenes, Escherichia coli, Klebsiella sp., Proteus sp., Staphylococcus sp. and Streptococcus sp. but their significance in uterine involution or fertility is largely unknown (Samad et al., 1984). Singh, Sharma, Singh \& Singh (1983) achieved a $57 \cdot 1 \%$ conception rate in repeat-breeding buffaloes with sub-clinical endometritis. In-vitro drug sensitivity tests on bacterial isolates and examination of uterine biopsies were found to be very useful in choosing appropriate treatment.

Although the uterus is extremely resistant to mycotic infection in the cow, there are reports correlating fungal infection with repeat breeder buffaloes (cited by Samad et al., 1984).

Repetitive sampling of 93 normal dairy cows for 7 weeks after calving revealed a reducing incidence of isolates with time as well as a fluctuating uterine flora as a result of spontaneous contamination, clearance and recontamination. Only infection with $C$. pyogenes was found to correlate positively with endometritis (Griffin, Hartigan \& Nunn, 1974).

Examination of the uteri of cows with endometritis yielded a variety of organisms similar to those that affect buffaloes. $C$. pyogenes was associated with the most severe uterine changes especially if in conjunction with Fusobacterium necrophorum (Ruder et al., 1981). Data from zebu are not yet available.

Endometritis in the cow is one cause of temporary subfertility (Fonseca, Britt, McDaniel, Wilk \& Rakes, 1983) and permanent infertility may result from degeneration and fibrosis of the endometrium or a blocking salpingitis (Vandeplassche \& Bouters, 1982).

Treatment of endometritis using local antibiotic therapy gives variable and often disappointing results (de Bois, 1982). Treatments aimed at the establishment of oestrous cycles would seem logical and if a corpus luteum is present the use of exogenous PG would seem appropriate (Jackson, 1977; Coulson, 1978). If no corpus luteum is present oestradiol benzoate may be the most suitable treatment.

Further clinical data are required for each species to determine the most appropriate treatment and subsequent effects on fertility.

\section{Retained fetal membranes}

The incidence of membranes being retained for $>12 \mathrm{~h}$ after normal parturition is $2-10 \%$ but 
can be as high as 20-30\%; after obstetrical problems an incidence of 23-55\% has been reported for buffaloes (Samad et al., 1984) and cows (cited by Arthur, Noakes \& Pearson, 1982).

Shorter intrauterine life-span of the fetus has been put forward as one predisposing cause in buffaloes (Awad, Youssif \& Mikhah, 1980) which would concur with suggestions for the condition in cows (Grunert, 1984) along with advanced involution of the placentomes, oedema or maceration of the chorionic villi, hyperaemia of the placentomes, placentitis and uterine inertia. All these changes are induced by abnormal hormone secretion in late pregnancy. Maturation of the placentomes depends on increased oestrogen secretion for $>5$ days with chronically low progesterone values for weeks before calving having a negative influence (Grunert, 1984). Treatments to remove severely retained membranes are rarely immediately successful as retention is a result of failed prepartum maturation. Necrosis has to take its course.

While the incidence of metritis in cows is in the region of $2 \%$, there is a dramatic increase to $55 \%$ after cases of retained membranes. The reduction in fertility associated with retained fetal membranes is usually as a result of this subsequent (endo)metritis.

Detailed studies on the impact of uterine infections upon reproductive efficiency in buffaloes and zebu have yet to be carried out.

\section{Specific infections of the female reproductive tract}

Little information is available for zebu. Campylobacter fetus or Vibrio fetus infection occurs in buffaloes and cows; the incidence is thought to be quite low ( $2 \%$ ) in buffaloes of Pakistan (cited by Samad et al., 1984) and in cows. Under natural service conditions venereal infection occurs. However, when AI is practised, the disease may be spread by infected semen unless antibiotics are added. As a preventive measure bulls are normally screened for such organisms.

The reported incidence of Brucella abortus is also quite low in buffaloes, about $2 \%$ (Samad $e t$ al., 1984), although a higher incidence $(5 \cdot 8 \%)$ may be observed on larger farms, suggesting that small village herds restrict spread of the disease. Many western countries have Brucella eradication programmes in operation for cows.

Tuberculosis is also more or less eradicated from western populations of cows; the incidence in buffaloes is not available. Similarly Trichomonas fetus is more or less under control in western cows; the incidence in buffaloes is not documented.

Leptospirosis in buffaloes and cows is not associated with a high incidence of abortions. However an incidence of $33-45 \%$ has been associated with repeat-breeding and anoestrous buffaloes (Samad et al., 1984). Recent serological surveys of cows in Britain have indicated that subclinical infections of Leptospira sp. may be more prevalent than previously thought (Ellis O'Brien \& Cassells, 1981).

\section{Hormonal induction of lactation}

In view of the prolonged periods of anoestrus in buffaloes and zebu which are aggravated by seasonal changes in reproductive efficiency it may be pertinent to investigate the possibility of inducing milk production by the application of exogenous hormones. For over 40 years attempts were made to induce lactation artificially in dairy cows, but this involved prolonged hormone administration with low rates of success. However, Smith \& Schanbacher (1973) established a method involving oestradiol and progesterone injections for only 7 days and, in spite of variable lactational performance, the technique looks promising. Any potential commercial exploitation would also depend on subsequent reproductive performance.

Consideration of this topic is not presented as an alternative to sound management but it may provide a means to maintain production while attempting to establish a normal pregnancy. 
Nulliparous or multiparous animals can be selected for treatment, usually those not seen in oestrus or those failing to conceive, but animals that abort early in the previous pregnancy can also be included. Initial studies began with twice daily subcutaneous injections of $0.05 \mathrm{mg}$ oestradiol $/ \mathrm{kg}$ body weight plus $0.125 \mathrm{mg}$ progesterone $/ \mathrm{kg}$ body weight given for 7 days, and attempts to reduce the variability of response have included the addition of dexamethasone, or reserpine, or thyrotrophin-releasing hormone to the regimen (Lembowicz, Rabek \& Skrzeczkowski, 1982).

Animals must have finished lactating for at least 1 month before hormone therapy to allow regeneration of the mammary epithelium. Production of milk is achieved in about $70 \%$ of the treated cows beginning 3-4 weeks after the start of treatment and reaching peak production 5 weeks later. In animals that do respond, colostrum is formed normally. Reports vary concerning the total milk yield but it would appear that yields obtained are $70-100 \%$ of previous production figures (Collier, Bauman \& Hays, 1975; Tervit et al., 1980).

Although the reproductive performances of only small numbers of cows have been studied, it appears that subsequent fertility is reasonable. Cows first come into oestrus 10-94 days after initiation of lactation and, in spite of frequent oestrous activity in some cows with cystic ovaries, pregnancy rates of $56-69 \%$ can be achieved. Reduction of the duration of steroid therapy to 5.5 or 3.5 days decreases the incidence of cystic ovaries (Lembowicz et al., 1982). Although oestrous behaviour does occur, especially during a 7-day or longer treatment, animals should not be inseminated then or immediately after treatment.

Further studies with lower steroid doses and/or reduced duration many be profitable, care being taken to assess tissue residues. Little information is available for buffaloes and zebu.

\section{Future research}

Artificial insemination is an excellent technique to improve breeds of livestock quickly as well as reducing the spread of (venereal) disease. Services for buffaloes and zebu are being developed, especially in Egypt, India and Pakistan. In each of these countries, semen can now be frozen and thawed, and still retain a useful viability. Services for milk recording and progeny testing of bulls, as well as for the performance testing of growth rate and draught ability, need to be established or strengthened in all major buffalo and zebu countries. In some areas, high-yielding dairy buffalo breeds are known to exist, such as the Murrah of India and the Nili-Ravi of Pakistan, and Hariana zebu of India, but little is known about their relative productivity and merit in comparison with other breeds. To improve overall production efficiency, genetic improvements may be made through cross-breeding programmes as well as studying genetic influences on features such as growth rates in heifers and calving intervals.

Modifications in management practices would also undoubtedly decrease prolonged calving intervals. Apart from strategic feeding and disease control regimens, manipulation of the length and pattern of suckling should result in earlier resumption of ovarian cyclicity. Management strategies to control infectious and parasitic infections and a reduction in environmental stresses, for example by provision of shade and showers, should improve the utilization and efficiency of utilization of available food for milk and meat production. Maximizing the growth rates of young stock and determination of optimal body weight for breeding should decrease the age at first calving, thus also greatly improving reproductive efficiency.

Examples have been given in this review of ways in which modern research techniques may be used to gain a greater understanding of the reproductive physiology of bovids. Extensions of this knowledge have led to field application of techniques such as synchronization of oestrus, AI and pregnancy diagnosis by hormone measurements. Reports concerning embryo transfer in buffaloes are also now beginning to appear (Drost, Wright, Cripe \& Richter, 1983), although such techniques will provide minor improvements compared to those gained by changes in breeding and management practices. Application of exogenous hormones to hasten puberty, to induce parturition or 
lactation, and to ensure earlier post-partum return to ovarian cyclicity have been mentioned, but again these are of major use in research, rather than in field, applications: simpler techniques of improved management will make greater impact on the world's buffalo and zebu populations along with attempts to improve the education of herdsmen in such areas of husbandry. It is also important to re-emphasize the importance of surveys and research on small village herds of buffaloes and zebu as this is where the majority of animals are kept.

It would appear that the generally low reproductive efficiency of zebu may be overcome by improved nutrition although this may not always be economical or possible. This species is better adapted to hot climates than the cow due mainly to skin attributes and disease resistance, and has excellent longevity with little dystocia (Turner, 1980). Therefore, in spite of the slow growth and low reproductive efficiency, crossbreeds of the two species are extremely valuable. For example, $50 \%$ Red Danish cows $\times$ Sahiwal zebu increased the first lactation yield from $1000 \mathrm{~kg}$ for pure Sahiwal to $2000 \mathrm{~kg}$ with a subsequent calving interval of 443 days compared to 467 days for the pure Sahiwal and 525 days for the pure Red Danish under similar conditions. The crossbreds also had lower abortion rates and calf mortality rates (Madsen \& Winther, 1975).

If a decision is to be made whether to produce milk from buffaloes or zebu cows in (sub)tropical areas, one of the major considerations involves the availability of different types of fodder. Calculation of financial returns over feed costs reveal very similar figures for both species if assessed on the basis of volume of solids-corrected milk. However, the superiority of buffaloes in obtaining nitrogen and mineral needs from poor quality forages may make them worth more than zebu for many situations (Sebastian, Mudgal \& Nair, 1970).

We are grateful to Professor C. R. Austin and Dr Barbara Weir for their encouragement.

\section{References}

Abeywardene, S.A., Hathorn, D.J. \& Glencross, R.G. (1984) Concentrations of oestradiol-17 $\beta$ and progesterone in bovine plasma and defatted milk during the post partum anovulatory period, during oestrous cycles and following ovariectomy. Br. vet. J. 140, 458-467.

Aboul-Ela, M.B., El-Keraby, F.E. \& Chesworth, J.M. (1983) Seasonal variation in the LH release in response to GnRH in buffalo. Anim. Reprod. Sci. 6, 229-232.

Aboule-Fadle, S.W., Fahmy, M.F.A. \& El-Shafey, S.M. (1974a) Histological studies on the ovaries of the Egyptian buffalo with special reference to the corpus luteum. Zentbl. VetMed. A21, 581-591.

Aboule-Fadle, S.W., Fahmy, M.F.A. \& El-Shafey, S.M. (1974b) Histological studies on the follicles with special reference to their atresia in Egyptian buffaloes. Zentbl. VetMed. A 21, 660-670.

Adeyemo, O. \& Heath, E. (1980) Plasma progesterone concentration in Bos taurus and Bos indicus heifers. Theriogenology 14, 411-419.

Adeyemo, O., Akpokodje, U.U. \& Odili, P.I. (1979) Control of estrus in Bos indicus \& Bos taurus heifers with prostaglandin $F_{2 a}$. Theriogenology 12, 255-262.

Adeyemo, O., Heath, E., Steinbach, J. \& Adadevoh, B.K. (1979) Estrous cycles in Bos indicus and Bos taurus heifers acclimatized to the hot humid seasonal equatorial climate. Zentbl. VetMed. A 26, 788-799.

Ahmed, N., Chaudry, R.A. \& Khan, B.B. (1981) Effect of month and season of calving on the length of subse- quent calving interval in Nili-Ravi buffaloes. Anim. Reprod. Sci. 3, 301-306.

Ainsworth, L. \& Ryan, K.J. (1966) Steroid hormone transformations by endocrine organs from pregnant mammals. 1. Estrogen biosynthesis by mammalian placental preparations in vitro. Endocrinology 79, 875-883.

Ainsworth, L. \& Ryan, K.J. (1967) Steroid hormone transformations by endocrine organs from pregnant mammals. II. Formation and metabolism of progesterone by bovine and sheep placental preparation in vitro. Endocrinology 81, 1349-1356.

Akbar, A.M., Reichert, L.E., Dunn, T.G., Kaltenbach, C.C. \& Niswender, G.D. (1974) Serum levels of follicle stimulating hormone during the bovine estrous cycle. J. Anim. Sci. 39, 360-365.

Alam, M.G.S. (1984) Abattoir studies of genital diseases in cows. Vet. Rec. 114, 195.

Al-Dahash, S.Y.A. \& David, J.S.E. (1977) The incidence of ovarian activity, pregnancy and bovine genital abnormalities shown by an abattoir survey. Vet. Rec. 101, 296-299.

Amin, S.O. \& El-Sheikh, A.S. (1973) Progesterone in placenta, uterine tissue and residual ovarian tissue of the Egyptian buffalo. Indian J. Anim. Sci. 43, 457-461.

Arnstadt, K.I. \& Cleere, W.F. (1981) Enzymeimmunoassay for determination of progesterone in milk from cows. J. Reprod. Fert. 62, 173-180.

Arora, R.C. \& Pandey, R.S. (1982a) Pattern of plasma 
progesterone, oestradiol-17 $\beta$, luteinizing hormone and androgen in non-pregnant buffalo (Bubalus bubalis). Acta endocr., Copenh. 100, 279-284.

Arora, R.C. \& Pandey, R.S. (1982b) Plasma concentrations of progesterone, oestradiol- $17 \beta$ and luteinizing hormone in relation to repeat breeding in buffalo (Bubalus bubalis). Anim. Prod. 34, 139-144.

Arora, R.C., Batra, S.K., Pahwa, G.S., Jain, G.C. \& Pandey, G.S. (1980) Milk progesterone levels to monitor reproductive status of Murrah buffalo. Theriogenology 13, 249-255.

Arthur, G.H., Noakes, D.E. \& Pearson, H. (1982) Veterinary Reproduction and Obstetrics, 5th edn. Bailliere Tindall, London.

Asdell, S.A. (1964) Patterns of Mammalian Reproduction, 2nd edn. Constable, London.

Avenell, J.A., Saepudin, Y. \& Fletcher, I.C. (1985) Concentrations of $\mathrm{LH}$, oestradiol $-17 \beta$ and progesterone in the peripheral plasma of swamp buffalo cows (Bubalus bubalis) around the time of oestrus. $J$. Reprod. Fert. 74, 419-424.

Awad, Y.L., Youssif, R.H. \& Mikhah, M.F. (1980) Individual factors of the calf as predisposing cause to retained placenta in the buffalo dam. J. Egyptian Vet. Med. Assoc. 40, 77-87.

Ayalon, N. (1978) A review of embryonic mortality in cattle. J. Reprod. Fert. 54, 483-493.

Bachlaus, N.K., Arora, R.C., Prasad, A. \& Pandey, R.S. (1980) Effect of prostaglandin $F_{2 \alpha}$-tham salt and Estrumate (ICI 80996) on plasma progesterone levels in Indian water buffaloes (Bubalus bubalis). Theriogenology 13, 297-303.

Ball, P.J.H. (1978) The relationship of age and stage of gestation to the incidence of embryonic death in dairy cattle. Res. Vet. Sci. 25, 120-122.

Ball, P.J.H. \& Lamming, G.E. (1983) Diagnosis of ovarian acyclicity in lactating dairy cows and evaluation of treatment with gonadotrophin-releasing hormone or a progesterone-releasing intravaginal device. $\mathrm{Br}$. vet. J. 139, 522-527.

Barnes, M.A., Kazmer, G.W., Brierly, S.T., Richardson, M.E. \& Dickey, J.R. (1980) Follicle stimulating hormone and estradiol 17 beta in dairy cows treated with a progesterone-releasing intravaginal device. $J$. Dairy Sci. 63, 161-165.

Batra, S.K. \& Pandey, R.S. (1982) Luteinizing hormone and oestradiol-17 $\beta$ in blood plasma and milk during the oestrous cycle and early pregnancy in Murrah buffaloes. Anim. Reprod. Sci. 5, 147-157.

Batra, S.K. \& Pandey, R.S. (1983a) Relative concentration of 13,14-dihydro-15-keto prostaglandin F-2 $\alpha$ in blood and milk of buffaloes during the oestrous cycle and early pregnancy. J. Reprod. Fert. 67, 191-195.

Batra, S.K. \& Pandey, R.S. (1983b) Luteinizing hormone in blood plasma of post partum buffaloes (Bubalus bubalis). Theriogenology 19, 193-200.

Batra, S.K., Arora, R.C., Bachlaus, N.K. \& Pandey, R.S. (1979) Blood and milk progesterone in pregnant and non-pregnant buffalo. J. Dairy Sci. 62, 1390-1393.

Batra, S.K., Pahwa, G.S. \& Pandey, R.S. (1982) Hormonal milieu around parturition in buffaloes (Bubalus bubalis). Biol. Reprod. 27, 1055-1061.

Beal, W.E. (1983) A note on synchronization of oestrus in post-partum cows with prostaglandin $F_{2 a}$ and a progesterone-releasing device. Anim. Prod. 37, 305-308.

Beck, T.W. \& Convey, E.M. (1977) Estradiol control of serum luteinizing hormone concentrations in the bovine. J. Anim. Sci. 45, 1096-1103.

Betteridge, K.J., Eaglesome, M.D., Randall, G.C.B. \& Mitchell, D. (1980) Collection, description and transfer of embryos from cattle 10-16 days after oestrus. J. Reprod. Fert. 59, 205-216.

Bhalaru, S.S., Dhillon, J.S. \& Tiwana, M.S. (1981) Effect of body weight at calving on body weight changes during early lactation and post partum reproductive performance in buffaloes. J. agric. Sci., Camb. 97, 595-597.

Bhattacharya, P. (1974) Reproduction. In The Husbandry and Health of the Domestic Buffalo, pp. 105-158. Ed. W. Ross Cockrill. F.A.O., Rome.

Bolander, F.F. Ulberg, L.C. \& Fellows, R.E. (1976) Circulating placental lactogen levels in dairy and beef cattle. Endocrinology 99, 1273-1278.

Bosu, W.T.K. (1982) The use of GnRH in bovine reproduction. The Compendium on Continuing Education 4, S55-S64.

Bulman, D.C. \& Lamming, G.E. (1978) Milk progesterone levels in relation to conception, repeat breeding and factors influencing acyclicity in dairy cows. $J$. Reprod. Fert. 54, 447-458.

Carr, W.R. (1972) Radioimmunoassay of luteinizing hormone in the blood of Zebu cattle. J. Reprod. Fert. 29, $11-18$.

Carruthers, T.D. \& Hafs, H.D. (1980) Suckling and four times daily milking; influence on ovulation, estrus and serum luteinizing hormone, glucocorticoids and prolactin in post-partum Holsteins. J. Anim. Sci. 50, 919-925.

Chauhan, F.S., Sharma, R.D. \& Singh, G.B. (1982) Responses of different doses of prostaglandin $F_{2}$ alpha on estrus induction, fertility and progesterone levels on subestrous buffaloes. Theriogenology 17, 247-253.

Collier, R.J., Bauman, D.E. \& Hays, R.L. (1975) Milk production and reproductive performance of cows hormonally induced into lactation. J. Dairy Sci. 58, $1524-1527$.

Cooper, M.J. (1974) Control of oestrous cycles of heifers with a synthetic prostaglandin analogue. Vet. Rec. 95, 200-203.

Coulson, A. (1978) Treatment of metritis in cattle with prostaglandin $\mathrm{F}_{2 \alpha}$. Vet. Rec. 103, 359.

Cribiu, E. P. \& Obeidah, A. (1978) The C-banding pattern of Egyptian water buffalo (Babalus bubalis). Annls Génét. Sél. anim. 10, 271-274.

de Bois, C.H.W. (1982) Some aspects of the therapy and prophylaxis of retained placenta and puerperal endometritis in the cow. In Factors Influencing Fertility in the Post-partum Cow, pp. 479-509. Eds H. Karg \& E. Schallenberger. Martinus Nijhoff, The Hague.

Dobson, H. (1978a) Plasma gonadotrophins and oestradiol during oestrus in the cow. J. Reprod. Fert. 52, 51-53.

Dobson, H. (1978b) Radioimmunoassay of FSH in the plasma of post-partum dairy cows. J. Reprod. Fert. 52, 45-49. 
Dobson, H. \& Dean, P.D.G. (1974) Radioimmunoassay of oestrone, oestradiol-17 $\alpha$ and $-17 \beta$ in bovine plasma during the oestrous cycle and last stages of pregnancy. J. Endocr. 61, 479486.

Dobson, H. \& Fitzpatrick, R.J. (1975) The effect of HCG or endogenous gonadotrophin on normal bovine follicular activity. J. Reprod. Fert. 43, 337-340.

Dobson, H. \& Fitzpatrick, R.J. (1976) Clinical application of the progesterone-in-milk test. Br. vet. J. 132, 538-542.

Dobson, H., Cooper, M.J. \& Furr, B.J.A. (1975) Synchronization of oestrus with ICI 79,939, an analogue of $\mathbf{P G F}_{2 a}$ and associated changes in plasma progesterone, oestradiol-17 $\beta$ and LH in heifers. $J$. Reprod. Fert. 42, 141-144.

Dobson, H., Midmer, S.E. \& Fitzpatrick, R.J. (1975) Relationship between progesterone concentrations of milk and plasma during the bovine oestrous cycle. Vet. Rec. 96, 222-223.

Dobson, H., Rankin, J.E.F. \& Ward, W.R. (1977) Bovine cystic ovarian disease: Plasma hormone concentrations and treatment. Vet. Rec. 101, 459-461.

Donaldson, L.E., Bassett, J.M. \& Thorburn, G.D. (1970) Peripheral plasma progesterone concentration of cows during puberty, oestrous cycles, pregnancy and lactation and effects of undernutrition or exogenous oxytocin on progesterone concentrations. J. Endocr. 48, 599626.

Drew, S.B., Gould, C.M. \& Bulman, D.C. (1978) The effect of treatment with a progesterone releasing intravaginal device on the fertility of spring-calving Friesian dairy cows. Vet. Rec. 103, 259-262.

Drost, M., Wright, J.M., Cripe, W.S. \& Richter, A.R. (1983) Embryo transfer in water buffalo (Bubalus bubalis). Theriogenology 20, 579-584.

Edqvist, L.E., Lindell, J.O. \& Kindahl, H. (1981) Prostaglandin $\mathrm{F}_{2 a}$ release at premature and normal term deliveries in the cow. Acta vet. scand., Suppl. 77, 267-277.

Eley, D.S., Thatcher, W.W., Head, H.H., Collier, R.J., Wilcox, C.J. \& Call, G.P. (1981) Periparturient and post partum endocrine changes of conceptus and maternal units in Jersey cows bred for milk yield. $J$. Dairy Sci. 64, 312-320.

El-Fouly, M.A., Kotby, E.A. \& El-Sobhy, H.E. (1976a) The functional reproductive peak in Egyptian buffalo cows is related to day length and ambient temperature. Arch. Vet. Ital. 7, 123-129.

El-Fouly, M.A., Kotby, E.A. \& El-Sobhy, A.E. (1976b) Effect of suckling on uterine and cervical involution in post partum Egyptian buffaloes. Indian J. Anim. Sci. 46, 221-227.

El-Fouly, M.A., Kotby, E.A., El-Sobhy, A.E. (1976c) Post partum ovarian activity in suckled and milked buffaloes. Theriogenology 5, 69-81.

Ellis, W.A., O'Brien, J.J. \& Cassells, J. (1981) Role of cattle in maintenance of Leptospira interrogans serotype hardjo infection in Northern Ireland. Vet. Rec. 108, 555-557.

Elsden, R.P. \& Kessler, R.M. (1983) Superovulation of Nebre cows and heifers. Theriogenology 19, 127 , abstr.

El-Sheikh, A.S. \& El-Fouly, M.A. (1971) Estrus, estrus cycle and time of ovulation in a herd of buffalo heifers. Alex. J. Agric. 19, 9-14.
El-Sheikh, A.S., Sakla, F.B. \& Amin, S.O. (1969) Changes in the density and progesterone content of the luteal tissue in the Egyptian buffalo during pregnancy. J. Endocr. 43, 1-8.

El-Wishy, A.B. (1979) Reproductive performance of Iraqi buffaloes 2 . Observations on the genital organs of slaughtered buffaloes. Beitrage trop, Landwirtsch. Veterinarmed. 17, 85-90.

El-Wishy, A.B., \& El-Sawaf, S.A. (1971) Reproduction in buffaloes in Egypt. III. Service period and its components. Z. Tierzucht Zücht. Biol. 87, 325-334.

El-Wishy, A.B., Abdou, M.S.S. \& El-Sawaf, S.A. (1971) Reproduction in buffaloes in Egypt. I. Fertility of buffaloes served at varying intervals after calving. Egyptian Vet. Med. J. Cairo, 19, 123-130.

Esslemont, R.J. (1982) Economic aspects related to cattle infertility and the post partum interval. In Factors Influencing Fertility in the Post-partum Cow, pp. 442 458. Eds H. Karg \& E. Schallenberger. Martinus Nijhoff, The Hague.

Esslemont, R.J., Eddy, R.G. \& Ellis, P.R. (1977) Planned breeding in autumn calving dairy herds. Vet. Rec. 100, 426-427.

Evans, G. \& Wagner, W.C. (1981) In vitro oestrogen synthesis by bovine placenta during pregnancy and induced parturition. Acta endocr., Copenh. 98, $119-125$.

Everitt, G.C. (1968) Prenatal development of uniparous animals with particular reference to the influence of maternal nutrition in sheep. In Growth and Development of Mammals, pp. 131-157. Eds G. A. Lodge \& G. E. Lamming. Butterworths, London.

Flint, A.P.F. (1984) Steroid effects on embryo survival: Role of luteal secretion of progesterone and oxytocin in the aetiology of embryo mortality. Proc. 10th Int. Congr. Anim. Reprod. \& A.I., Urbana Vol. IV, pp. XIII-22-XIII-25.

Flint, A.P.F., Anderson, A.B.M., Patten, P.T. \& Turnbull, A.C. (1974) Control of utero-ovarian venous prostaglandin F during labour in the sheep: acute effects of vaginal and cervical stimulation. $J$. Endocr. 63, 67-87

Fonesca, F.A., Britt, J.H., McDaniel, B.T., Wilk, J.C. \& Rakes, A.H. (1983) Reproductive traits of Holsteins and Jerseys. Effects of age, milk yield and clinical abnormalities on involution of the cervix and uterus, estrous cycles, detection of oestrus, conception rate and days open. J. Dairy Sci. 66, 1128-1147.

Fosgate, O.T. \& Smith, V.R. (1954) Prenatal mortality in the bovine between pregnancy diagnosis at 34-50 days post-insemination and parturition. J. Dairy Sci. 37, 1071-1073.

Foster, D.L., Yellon, S.M. \& Olster, D.H. (1984) Endocrine physiology of puberty in the female sheep. Proc. 10th Int. Congr. Anim. Reprod. \& A.I., Urbana, Vol. IV, pp. VII-6-VII-23.

Foulkes, J.A., Cookson, A.D. \& Sauer, M.J. (1982) AI in cattle based on daily microtitre plate enzyme immunoassay of progesterone in whole milk. Br. vet. J. 138, 515-521.

Galhotra, M.M., Kaker, M.L. \& Razdan, M.N. (1981) Serum LH levels during pre- and post-puberty, pregnancy and lactation in Murrah buffaloes. Theriogenology 16, 477-481

Ghannam, S.A.M. \& Deeb, S. (1966) Histological study 
on the endometrium of buffalo with special reference to the anatomical changes in the ovaries. J. Arab. Vet. Med. Assoc. 26, 293.

Glencross, R.G. (1984) A note on the concentrations of plasma oestradiol-17 $\beta$ and progesterone around the time of puberty in heifers. Anim. Prod. 39, 137-140.

Glencross, R.G. \& Abeywardene, S.A. (1983) Concentrations of oestradiol-17 $\beta$ and progesterone in plasma and defatted milk of cattle during the oestrous cycle. Br. vet. J. 139, 49-51.

Glencross, R.G. \& Pope, G.S. (1981) Concentrations of oestradiol-17 $\beta$ and progesterone in the plasma of dairy heifers before and after cloprostenol-induced and natural luteolysis and during early pregnancy. Anim. Reprod. Sci. 4, 93-106.

Gonzalez-Padilla, E., Wiltbank, J.N. \& Niswender, G.D. (1975a) Puberty in beef heifers. 1. The inter-relationship between pituitary, hypothalamic and ovarian hormones. J. Anim. Sci. 40, 1091-1104.

Gonzalez-Padilla, E., Niswender, G.D. \& Wiltbank, J.N. (1975b) Puberty in beef heifers. II. Effect of injections of progesterone and estradiol-17 $\beta$ on serum $\mathrm{LH}$, FSH and ovarian activity. $J$. Anim. Sci. 40, 1105-1109.

Gonzalez-Padilla, E., Ruiz, R., LeFever, D., Denham, A. \& Wiltbank J.N. (1975c) Puberty in beef heifers. III. Induction of fertile oestrus. J. Anim. Sci. 40, $1110-1118$

Goodman, R.L. \& Karsch, F.J. (1981) A critique of the evidence on the importance of steroid feedback to seasonal changes in gonadotrophin secretion. $J$, Reprod. Fert., Suppl. 30, 1-13.

Grifiin, J.F.T., Hartigan, P.J. \& Nunn, W.R. (1974) Non-specific uterine infection and bovine fertility. I. Infection patterns and endometritis during the first seven weeks post partum. Theriogenology 1, 91-105.

Grunert, E. (1984) Placental separation/retention in the bovine. Proc. 10th Int. Congr. Anim. Reprod. \& A.I., Urbana Vol. IV, pp. XI-17-XI-24.

Hafez, E.S.E. (1954) Oestrus and some related phenomena in the buffalo. J. agric. Sci., Camb. 44, 165-172

Hamon, M., Fleet, I.R., Holdsworth, R.J. \& Heap, R.B. (1981) The time of detection of oestrone sulphate in milk and diagnosis of pregnancy in cows. Br. vet. $J$. 137, 71-77.

Hansel, W. (1981) Plasma hormone concentrations associated with early embryo mortality in heifers. $J$. Reprod. Fert., Suppl. 30, 231-239.

Heap, R.B., Holdsworth, R.J., Gadsby, J.E., Laing, J.A. \& Walters, D.E. (1976) Pregnancy diagnosis in the cow from milk progesterone concentration. Br. vet. J. $132,445-464$.

Hoffman, B., Schams, D., Gimenez, T., Ender, M.L., Herrman, C. \& Karg, H. (1973) Changes of progesterone, total oestrogens, corticosteroids, prolactin and $\mathrm{LH}$ in bovine peripheral plasma around parturition with special reference to the effect of exogenous corticoids and a prolactin inhibitor respectively. Acta endocr., Copenh. 73, 385-395.

Hoffman, B., Gunzler, O., Hamburger, R. \& Schmidt, W. (1976) Milk progesterone as a parameter for fertility control in cattle; methodological approaches and present status of application in Germany. Br. vet. $J$. 132, $469-476$.
Hunter, J.T., Fairclough, R.J., Peterson, A.J. \& Welch, R.A.S. (1977) Foetal and maternal hormonal changes preceding normal bovine parturition. Acta endocr., Copenh. 84, 653-662.

Hunter, R.H.F. (1980) Transport and storage of spermatozoa in the female tract. Proc. $9 \mathrm{th}$ Int. Cong. Animal Reprod. \& A.I. Madrid, II, pp. 227-233.

Jackson, P.S. (1977) Treatment of chronic post partum endometritis in cattle with cloprostenol. Vet. Rec. 101, $441-443$.

Jain, G.C. \& Pandey, R.S. (1984) Ovulatory changes in the levels of prostaglandin $F_{2 a}$, luteinizing hormone, oestradiol-17 $\beta$ and progesterone in buffaloes (Bubalus bubalis). Zentbl. VetMed. A 31, 205-212.

Jainudeen, M.R. (1976) Induction of oestrus and ovulation in buffalo (Bubalus bubalis) using a prostaglandin $\mathrm{F}_{2 a}$ analogue (ICI 80996). Proc. 8th Int. Congr. Animal Reprod. \& A.I., Krakow 3, 470-472.

Jainudeen, M.R. (1984) Reproduction in the water buffalo: post partum female. Proc. 10th Int. Congr. Animal Reprod. \& A.I., Urbana, Vol. IV, pp. XIV-42-XIV-49

Jainudeen, M.R., Bongso, T.A. \& Tan, H.S. (1982) Post partum ovarian activity and uterine involution in the suckled swamp buffalo (Bubalus bubalis). Anim. Reprod. Sci. 5, 181-190.

Jainudeen, M.R., Sharifuddin, W. \& Bashir Ahmad, F. (1983) Relationship of ovarian contents to plasma progesterone concentration in the swamp buffalo (Bubalus bubalis). Vet. Rec. 13, 369-372.

Jöchle, W. (1972) Seasonal fluctuations of reproductive functions in Zebu cattle. Int. J. Biomet. 16, 131-144.

Jöchle, W. (1975) Use of progestogens in cattle under tropical or subtropical conditions. Annls Biol. anim. Biochim. Biophys. 15, 281-290.

Johnson, C.T. (1981) Induction of parturition in cattle. Acta vet. scand., Suppl. 7, 311-319.

Kaker, M.L., Razdan, M.N., Galhotra, M.M. (1980) Serum LH concentrations in cyclic buffalo (Bubalus bubalis ). J. Reprod. Fert. 60, 419-424.

Kaker, M.L., Murray, R.D. \& Dobson, H. (1984) Plasma hormone changes in cows during induced or spontaneous calvings in the early post partum period. Vet. Rec. 115, 378-383.

Kamonpatana, M. (1984) Application of hormone assays and endocrine patterns in buffalo. Proc. 10th Int. Congr. Anim. Reprod \& A.I., Urbana, Vol. IV, pp. XIV-1-XIV-9.

Kamonpatana, M., Kunawongkvit, A., Bodhipaksha, P. \& Luvira, Y. (1979a) Effect of PGF-2 $\alpha$ on serum progesterone levels in the swamp buffalo (Bubalus bubalis). J. Reprod. Fert. 56, 445-449.

Kamonpatana, M., Chantaraprateep, P. \& Ngramsuriyaroj, C. (1981) A herd test for non-pregnancy using plasma progesterone levels in the selection of swamp buffalo for oestrus synchronization. Br. vet. J. 137, $173-175$.

Kamonpatana, M., van de Wiel, D.F.M., Koops, W., Leenanuruksa, LD., Ngramsuriyaroj, C. \& Usanakornkul, S. (1979b) Oestrus control and early pregnancy diagnosis in the swamp buffalo: comparison of enzyme immunoassay and radioimmunoassay for plasma progesterone. Theriogenology 11, 399-409.

Kamonpatana, M., Ngramsuriyaroj, C., Srisakwattana, 
K. \& Chantaraprateep, P. (1983a) Milk progesterone levels in crossbred buffaloes (swamp and Murrah) and a comparison to the original breeds. Theriogenology 19, 713-725.

Kamonpatana, M., Parnpai, R., Ngramsuriyaroj, C. \& Srisakwattana, K. (1983b) Plasma progesterone, oestrone and oestrone sulphate levels during the first half of gestation in swamp buffaloes. Br. vet. J. 139, 256-261.

Kanai, Y. \& Shimizu, H. (1983) Characteristics of the estrous cycle of the swamp buffalo under temperate conditions. Theriogenology 19, 593-603.

Kanai, Y. \& Shimizu, H. (1984) Plasma concentrations of LH progesterone and oestradiol during the oestrous cycle in swamp buffaloes (Bubalus bubalis). J. Reprod. Fert. 70, 507-510.

Kaur, H. \& Arora, S.P. (1984) Annual pattern of plasma progesterone in normal cycling buffaloes (Bubalus bubalis) fed two levels of nutrition. Anim. Reprod. Sci. 7, 323-332.

Kay, H.D. (1974) Milk and milk production. In The Husbandry and Health of the Domestic Buffalo, pp. 329-376. Ed. W. Ross Cockrill. F.A.O. Rome.

Kesner, J.S., Convey, G.M. \& Anderson, C.R. (1981) Evidence that estradiol induces the preovulatory LH surge in cattle by increasing pituitary sensitivity to LHRH and then increasing LHRH release. Endocrinology 108, 1386-1394.

Kidder, H.E., Black, W.G., Wiltbank, H.N., Ulberg, L.C. \& Casida, L.E. (1954) Fertilization rates and embryonic death rates in cows bred to bulls of different leveis of fertility. J. Dairy Sci. 37, 691 .

Kindahl, H., Edqvist, L.E., Bane, L. \& Granstrom, L. (1976) Blood levels of progesterone and 15-keto-13,14,dihydro prostaglandin $F_{2 \alpha}$ during normal oestrous cycle and early pregnancy. Acta endocr., Copenh. 82, 134-149.

Kindahl, H., Lindell, J.O. \& Edqvist, L.E. (1980) On the control of prostaglandin release during the bovine oestrous cycle. Effects of cloprostenol injections. Nord. VetMed. 32, 467-473.

Kindahl, H., Frederiksson, G., Madej, A. \& Edqvist, L.E. (1984) Role of prostaglandins in uterine involution. Proc. 10th Int. Congr. Anim. Reprod. \& A.I., Urbana, Vol. IV, pp. XI-9-XI-16.

King, G.J., Atkinson, B.A. \& Robertson, H.A. (1982) Implantation and early placentation in domestic ungulates. J. Reprod. Fert., Suppl. 31, 17-30.

Kiser, T.E., Dunlap, S.E., Benyshek, L.L. \& Mares, S.E. (1980) The effect of calf removal on estrous response and pregnancy rate of beef cows after Synchromate-B treatment. Theriogenology 13, 381-389.

Koprowski, J.A. \& Tucker, H.A. (1973) Serum prolactin during various physiological states and its relationship to milk production in the bovine. Endocrinology 92, 1480-1487.

Kumi-diaka, J., Ogwu, D. \& Osori, D.I.K. (1981) Significance of atrophic ovaries in livestock production in Northern Nigeria. Vet. Rec. 108, 277-278.

Lamming, G.E. (1978). Reproduction during lactation. In Control of Ovulation, pp. 335-353. Eds D. B. Crighton, N. B. Haynes, G. R. Foxcroft \& G. E. Lamming. Butterworth, London.

Lee, J.A., Roussel, J.D. \& Beatty, J.R. (1976) Effect of temperature season on bovine adrenal cortisol function, blood cell profile and milk production. $J$. Dairy Sci. 59, $104-108$.

Lembowicz, K., Rabek, A. \& Skrzechzkowski, L. (1982) Hormonal induction of lactation in the cow. Br. vet. J. 138, 203-208.

Linares, T., Larson, T. \& Edqvist, L.E. (1982) Plasma progesterone levels from oestrus through Day 7 after A.I. in heifers carrying embryos with normal or deviating morphology. Theriogenology 17, 125-132.

Luktuke, S.N. \& Subramanian, P. (1961) Studies on certain aspects of the oestrous phenomenon in Hariana cattle. J. Reprod. Fert. 2, 199-200.

Luktuke, S.N. \& Rao, A.S.P. (1962) Studies on biometry of the reproductive tract of the buffalo cow. Indian $J$. vet. Sci. 32, 106-111.

Lundström, K., Abeygunawardena, H., de Silva, L.N.A. \& Perera, B.M.A.O. (1982) Environmental influence on calving interval and estimates of its repeatability in the Murrah Buffalo in Sri Lanka. Anim. Reprod. Sci. 5, 99-109.

MacDonald, L.E., McNutt, S.H. \& Nichols, R.E. (1953) On the essentiality of the bovine corpus luteum of pregnancy. Am. J. vet. Res. 14, 539-541.

Macmillan, K.L., Day, A.M., Taula, V.K., Gibb, M. \& Pearce, M.G. (1985) Effects of an agonist of gonadotrophin releasing hormone in cattle. III Conception rates after luteal phase injections. Anim. Reprod. Sci. 10 (in press).

Madsen, O. \& Winther, K. (1975) Performance of pure bred and crossbred dairy cattle in Thailand. Anim. Prod. 21, 209-216.

Manwell, C. \& Baker, C.M.A. (1980) Chemical classification of cattle. 2. Phylogenetic tree and specific status of Zebu. Anim. Blood Grps. biochem. Genet. 11, $151-162$.

Mapletoft, R.J., Lewing, F. \& Wilson, D.C. (1984) Induction of parturition in the cow with a combination of cloprostenol and dexamethasone. Proc. 10th Int. Congr. Anim. Reprod. \& A.I., Urbana, Vol. II, Brief Paper 105.

Mason, I.L. (1974) The water buffalo, species types and breeds. In The Husbandry and Health of the Domestic Buffalo, pp. 88-104. Ed. W. Ross Cockrill. F.A.O., Rome.

Maule Walker, F.M., Davis, A.J. \& Fleet, I.R. (1983) Endocrine activity of the mammary gland: oestrogen and prostaglandin secretion by the cow and sheep mammary glands during lactogenesis. $B r$. vet. J. 139, 171-177.

Mehta, S.N., Gangwar, P.C., Srivastava, R.K. \& Dhingra, D.P. (1979) Effect of cooling on reproductive behaviour in buffaloes (Bos bubalis). J. agric. Sci., Camb. 93, 249-251.

Melampy, R.M., Hearn, W.R. \& Rakes, J.M. (1959) Progesterone content of bovine reproductive organs and blood during pregnancy. J. Anim. Sci. 18, 307-313.

Miksch, E.D., LeFever, D.G., Mukembo, G., Spitzer, J.C. \& Wiltbank, H.N. (1978) Synchronization of estrus in beef cattle. II. Effect of an injection of norgestomet and an estrogen in conjunction with a norgestomet implant in heifers and cows. Theriogenology 10, 201-221.

Milk Marketing Board of England and Wales (1980) Dairy Facts and Figures, 1980. Thames Ditton, Surrey. 
Mobarak, A.M. (1969) Anatomical studies of the female genitalia of buffaloes. Vet. Med. J. Giza (Egypt) 16, $91-118$.

Morrow, D.A., Roberts, S.J. \& McEntee, K. (1966) Post partum ovarian activity and uterine involution in dairy cattle. J. Am. vet. med. Assoc. 149, 1596-1690.

Morrow, D.A., Roberts, S.J. \& McEntee, K. (1969) A review of post partum ovarian activity and involution of the uterus and cervix in cattle. Cornell Vet. 59, 134-154.

Murray, R.D., Nutter, W.T., Wilman, S. \& Harker, D.B. (1982) Induction of parturition in a commercial dairy herd: clinical management and treatment. Vet. Rec. 111, 363-365.

Nagaratnam, V., Sooriyamoorthy, T., Oyedipe, E.O. \& Zakari, A.Y. (1983) Synchronization of oestrus with cloprostenol and subsequent calving rates in artificially inseminated Zebu heifers. Br. vet. J. 139, 440-444.

Nancarrow, C.D., Wallace, A.L.C. \& Grewal, A.S. (1981) The early pregnancy factor of sheep and cattle. $J$. Reprod. Fert., Suppl. 30, 191-199.

Niswender, G.D., Reichert, L.E., Midgley, A.R. \& Nalbandov, A.V. (1969) Radioimmunoassay for bovine and ovine luteinizing hormone. Endocrinology 84, $1166-1172$.

Oltner, R. \& Edqvist, L.E. (1981) Progesterone in defatted milk: its relation to insemination and pregnancy in normal cows as compared with cows on problem farms and individual problem animals. Br. vet. $J .137$, 78-87.

Orihuela, A., Galina, C., Escobar, J. \& Riquelme, E. (1983) Estrous behaviour following prostaglandin $F_{2 a}$ injection in Zebu cattle under continuous observation. Theriogenology 19, 795-809.

Osinga, A. \& Hazeleger, W. (1979) The influence of the sire on the oestrogen production of the bovine foetusplacental unit. In Calving Problems and Early Viability of the Calf, pp. 282-292. Eds. B. Hoffman, I. L. Mason \& J. Schmidt. Martinus Nijhoff, The Hague.

Oyedipe, E.O., Osori, D.I.K., Akerejola, O. \& Saror, D. (1982) Effect of level of nutrition on onset of puberty and conception rates of Zebu heifers. Theriogenology 18, 525-539.

Pahwa, G.S. \& Pandey, R.S. (1983) Hormonal changes in post-partum blood plasma and milk of buffaloes (Bubalus bubalis). Anim. Prod. 37, 237-246.

Pandey, R.S., Pahwa, G.S., Suri, A.K. \& Batra, S.K. (1981) Diurnal variations of oestradiol $17 \beta$ in milk of cross-bred cows during the oestrous cycle and early pregnancy. Br. vet. J. 137, 596600 .

Pant, H.C. \& Sharma, B.L. (1979) The effect of melengesterol acetate and oestradiol benzoate in the treatment of anoestrus in cattle. Vet. Rec. 104, 603-604.

Pathiraja, N., Abeyratne, A.S., Perera, B.M.A.O. \& Buvanendran, V. (1979) Fertility in buffaloes after oestrus synchronization with cloprostenol and fixed time inseminations. Vet. Rec. 104, 279-281.

Pelletier, J., Carrez-Camous, S. \& Thiery, J.C. (1981) Basic neuroendocrine events before puberty in cattle, sheep and pigs. J. Reprod. Fert., Suppl. 30, 91-102.

Perera, B.M.A.O., Pathiraja, N., Kumaratilake, W.L.J.S., Abeyratne, A.S. \& Buvanendran, V. (1977)
Synchronization of oestrus and fertility in buffaloes using a prostaglandin analogue. Vet. Rec. 101, 520-521.

Perera, B.M.A.O., Pathiraja, N., Abeywardena, S.A., Motha, M.X.J. \& Abeygunawardena, H. (1980) Early pregnancy diagnosis in buffaloes from plasma progesterone concentrations. Vet. Rec. 106, 104-106.

Perera, B.M.A.O., Abeygunawardena, H., Thamotharam, A., Kindahl, H. \& Edqvist, L.E. (1981) Peripartal changes of estrone, progesterone and prostaglandin in the water buffalo. Theriogenology 15, 463-467.

Peters, A.R. \& Lamming, G.E. (1984) Endocrine changes in the post-partum period. Proc. 10th Int. Congr. Anim. Reprod. \& A.I., Urbana, Vol. IV, pp. III-7-III-24.

Peters, A.R. \& Riley, G.M. (1982) Milk progesterone profiles and factors affecting post partum ovarian activity in beef cows. Anim. Prod. 34, 145-152.

Plasse, D., Koger, M. \& Warwick, A.C. (1968a) Reproductive behaviour of Bos indicus females in a subtropical environment. III. Calving intervals, intervals from first exposure to conception and intervals from parturition to conception. J. Anim. Sci. 27, 105-112.

Plasse, D., Warnick, A.C. \& Koger, M. (1968b) Reproductive behaviour of Bos indicus females in a subtropical environment. I. Puberty and ovulation frequency in Brahman and Brahman $\times$ British heifers. J. Anim. Sci. 27, 94-100.

Plasse, D., Warnick, A.C. \& Koger, M. (1968c) Reproductive behaviour of Bos indicus females in a subtropical environment. II. Gestation length in Brahman cattle. J. Anim. Sci. 27, 101-104.

Plasse, D., Warnick, A.C. \& Koger, M. (1970) Reproductive behaviour of Bos indicus females in a subtropical environment. IV. Length of estrous cycle, duration of estrus, time of ovulation, fertilization and embryo survival in grade Brahman heifers. J. Anim. Sci. 30, 63-72.

Pope, G.S., Majzlik, I., Ball, P.J.H. \& Leaver, J.D. (1976) Use of progesterone concentrations in plasma and milk in the diagnosis of pregnancy in domestic cattle. Br. vet. J. 132, 497-506.

Potter, W.L., Upton, P.C., Cooper, J. \& Blackshaw, A.W. (1979) C- and G-banding patterns and chromosomal morphology of some breeds of Australian cattle. Aust. vet. J. 55, 560-571.

Rahe, C.H., Owens, R.E., Fleeger, J.L., Newton, H.J. \& Harms, P.G. (1980) Pattern of plasma luteinizing hormone in the cyclic cow. Endocrinology 107, 498-503.

Ranka, A.M. \& Igboeli, G. (1971) Effects of nutrition, season and age on the estrous cycle of indigenous central African cattle. J. Anim. Sci. 32, 943-945.

Rahka, A.M., Igboeli, G. \& Hale, D. (1970) The oestrous cycle of Zebu and Sanga breeds of cattle in Central Africa. J. Reprod. Fert. 23, 411-414.

Rajakoski, E. (1960) The ovarian follicular system in sexually mature heifers with special reference to seasonal, cyclical and left-right variation. Acta endocr., Copenh., Suppl. 52, 7-68.

Rajamahendran, R., Jayatilaka, K.N., Dharmawardena, J. \& Thamotharam, M. (1980) Oestrus synchronization in buffaloes (Bubalus bubalis). Anim. Reprod. Sci. 3, 107-112.

Rajamahendran, R. \& Thamotharam, M. (1983) Effect of 
progesterone releasing intravaginal device (PRID) on fertility in the post-partum buffalo cow. Anim. Reprod. Sci. 6, 111-118.

Rao, A.R. (1981) Synchronization of oestrus in buffaloes with a progesterone releasing intravaginal device. Vet. Rec. 109, 123.

Rao, A.R. \& Rao Ch.C. (1983) Synchronization of oestrus and fertility in buffaloes with a progesterone releasing intravaginal device. Vet. Rec. 113, 623-624.

Rao, A.R. \& Rao, S.V. (1978) Synchronization of oestrus in buffaloes with cloprostenol. Vet. Rec. 103, 288.

Rao, A.R. \& Rao, S.V. (1979a) Treatment of suboestrus in buffaloes with cloprostenol. Vet. Rec. 105, $168-169$.

Rao, A.R. \& Rao, S.V. (1979b) Synchronization of oestrus in buffaloes with Norgestomet. Vet. Rec. 105, 256.

Rao, A.V.N. (1982) Causes and incidence of reproductive disorders among Zebu cross Taurus cross-bred cows in Andhra Pradesh. Theriogenology 17, 189.

Rao, A.V.N. \& Sreemannarayana, O. (1982) Clinical analysis of reproductive failure among female buffaloes (Bubalus bubalis) under village management in Andhra Pradesh. Theriogenology 18, 403-411.

Rao, A.V.N. \& Sreemannarayana, O. (1983) Induction of ovulatory estrus and fertility in non-cycling buffaloes with Norgestomet during low breeding season. Theriogenology 19, 305-309.

Rao, L.V. \& Pandey, R.S. (1983) Seasonal variations in plasma glucocorticoid levels in buffalo cows (Bubalus bubalis). Anim. Reprod. Sci. 6, 177-184.

Razdan, M.N., Kaker, M.L. \& Galhotra, M.M. (1981) Serum luteinizing hormone levels of non-cycling buffaloes (Bubalus bubalis). Indian J. Anim. Sci. 51, $286-288$.

Razdan, M.N., Kaker, M.L. \& Galhotra, M.M. (1982) Serum FSH levels during estrus and a 4-week period following mating in Murrah buffaloes (Bubalus bubalis). Theriogenology 17, 175-181.

Riley, G.M., Peters, A.R. \& Lamming, G.E. (1981) Induction of pulsatile $\mathrm{LH}$ release, $\mathrm{FSH}$ release and ovulation in post-partum acyclic beef cows by repeated small doses of GnRH. J. Reprod. Fert. $\mathbf{6 3}$, 559-565.

Robertson, H.A. (1974) Changes in the concentration of unconjugated oestrone, oestradiol-17 $\alpha$ and oestradiol-17 $\beta$ in maternal plasma of the pregnant cow in relation to the initiation of parturition and lactation. J. Reprod. Fert. 36, 1-7.

Robertson, H.A. \& King, G.J. (1979) Conjugated and unconjugated oestrogens in fetal and maternal fluids of the cow throughout pregnancy. J. Reprod. Fert. 55, $463-470$.

Roche, J.F. (1977) Control of ovulation and fixed time insemination in heifers following cloprostenol. Vet. Rec. 100, 468-470.

Roche, J.F., Boland, M.P. \& McGeady, T.A. (1981) Reproductive wastage following artificial insemination of heifers. Vet. Rec. 109, 401-404.

Roche, J.F. \& Gosling, J.P. (1977) Control of estrus and progesterone levels in heifers given intravaginal progesterone coils and injections of progesterone and estrogen. J. Anim. Sci. 44, 1026-1029.

Roche, F., Prendeville, D.J. \& Davis, W.D. (1977) Calving rate following fixed time insemination after a 12-day progesterone treatment in dairy cows, beef cows and heifers. Vet. Rec. 101, 417-419.

Roy, A., Raizada, B.C., Tiwari, R.B.L., Pandey, M.D., Yadva, P.D. \& Sengupta, B.P. (1968) Effect of management on the fertility of buffalo cows bred during summer. Indian J. Dairy Sci. 38, 554-560.

Roy, D.J. \& Luktuke, S.N. (1962) Studies on involution of the uterus in buffalo. Indian J. Vet. Sci. 32, 208-213.

Roy, D.T., Bhattacharya, A.R. \& Luktuke, S.N. (1972) Oestrus and ovarian activities of buffaloes in different months. Indian vet. J. 49, 54-60.

Ruder, C.A., Sasser, R.G., Williams, R.J., Ely, J.K., Bull, R.C. \& Butler, J.E. (1981) Uterine infections in the post-partum cow. II. Possible synergistic effect of Fusobacterium necrophorum \& Corynebacterium pyogenes. Theriogenology 15, 573-580.

Samad, H.A., Ali, C.S., Ahmad, K.M. \& Najibur-Rehman (1984) Reproductive diseases of the water buffalo. Proc. 10th Int. Congr. Anim. Reprod. \& A.I., Urbana, Vol. IV, pp. XIV-25-XIV-33.

Schams, D. (1983) Oxytocin determination by radioimmunoassay. III. Improvement to subpicrogram sensitivity and application to blood levels in cyclic cattle. Acta endocr., Copenh. 103, 180-183.

Schams, D. \& Prokopp, S. (1979) Oxytocin determination by RIA in cows around parturition. Anim: Reprod. Sci. 2, 267-270.

Schams, D. \& Schallenberger, E. (1976) Heterologous radioimmunoassay for bovine follicle-stimulating hormone and its application during the estrous cycle in cattle. Acta endocr., Copenh. 81, 461-473.

Schams, D., Hoffman, B., Fischer, S., Merz, E. \& Karg, H. (1972) Simultaneous determination of LH and progesterone in peripheral bovine blood during pregnancy, normal and corticoid-induced parturition and the post-partum period. J. Reprod. Fert. 29, $37-48$.

Schams, D., Schallenberger, E., Hoffman, B. \& Karg, H. (1977) Hormonal parameters and time relationship concerning oestrus, ovulation and electrical resistance of the vaginal mucus. Acta endocr., Copenh. 86, $180-192$.

Schams, D., Schallenberger, E., Menzer, Ch., Strangl, J., Zoltmeier, K., Hoffman, B. \& Karg, H. (1978) Profiles of LH, FSH and progesterone in post partum dairy cows and their relationship to the commencement of cyclic functions. Theriogenology 10, 453-468.

Schams, D., Schallenberger, E., Gombe, S. \& Karg, H. (1981) Endocrine patterns associated with puberty in male and female cattle. J. Reprod. Fert., Suppl. 30, 103-110.

Schultz, R.H. \& Copeland, D.D. (1981) Induction of abortion using prostaglandins. Acta vet. scand., Suppl. 77, 353-361.

Sebastian, L., Mudgal, V.D. \& Nair, P.G. (1970) Comparative efficiency of milk production by Sahiwal cattle and Murrah buffalo. J. Anim. Sci. 30, 253-256.

Sharifuddin, W. \& Jainudeen, M.R. (1983) The accuracy of rectal diagnosis of corpora lutea in water buffalo (Bubalus bubalis). Anim. Reprod. Sci. 6, 185-189.

Shaw; F.D. \& Morton, H. (1980) The immunological approach to pregnancy diagnosis. A review. Vet. Rec. 106, 268-269.

Shelton, J.N. \& Summers, P.M. (1983) Progesterone and 
estradiol-17 $\beta$ in the peripheral plasma of Brahman cows with single and twin pregnancies. Theriogenology 20, 47-52.

Short, R.E. \& Bellows, R.A. (1971) Relationships amongst weight gains, age at puberty and reproductive performance in heifers. J. Anim. Sci. 32, 127-131.

Singh, A. \& Puthiyandy, R. (1980) Estimation of progesterone in buffalo milk and its application to pregnancy diagnosis. J. Reprod. Fert. 59, 89-93.

Singh, G., Singh, G.B., Sharma, R.D. \& Nanda, A.S. (1983) Experimental treatment of summer anoestrous-buffaloes with Norgestomet and PRID. Theriogenology 19, 323-329.

Singh, G., Singh, G.B., Sharma, S.S. \& Sharma, R.D. (1984) Studies on oestrous symptoms of buffalo heifers. Theriogenology 21, 849-858.

Singh, G.B., Dugweka, Y.G., Sharma, R.D., Chauhan, F.S. \& Singh, M. (1979a) Treatment of suboestrous in buffaloes with prostaglandin $\mathrm{F}_{2 a}$. Vet. Rec. 104, 412413.

Singh, N., Chauhan, F.S. \& Singh, M. (1979b) Post partum ovarian activity and fertility in buffaloes. Indian J. Dairy Si. 32, 134-139.

Singh, R.B., Sharma, R.D., Singh, N. \& Singh, G.B. (1983) Bio-histopathological studies of endometrium in repeat breeding buffaloes (Bubalus bubalis). Theriogenology 19, 151-157.

Smith, J., El-Dessouky, F., Al-Ansari, G., Loftah, H.D. \& Injidi, M. (1971) A study of the reproductive tracts of female water buffaloes in Iraq. Br. vet. J. 127, $425-429$.

Smith, K.L. \& Schanbacher, F.L. (1973) Hormone induced lactation in the bovine. I. Lactational performance following injections of $17 \beta$-oestradiol and progesterone. J. Dairy Sci. 56, 738-743.

Snook, R.B., Saatman, R.R. \& Hansel, W. (1971) Serum progesterone and luteinizing hormone levels during the bovine estrous cycle. Endocrinology 88, 678 686 .

Sorensen, A.J., Hansel, W., Hough, W.H., Armstrong, D.T., McEntee, K. \& Bratton, R.W. (1959) Causes and prevention of reproductive failures in dairy cattle. I. Influence of underfeeding and overfeeding on growth and development of Holstein heifers. Bull. Cornell Univ. agric. Exp. Stn, pp. 936-951.

Stabenfeldt, G.H., Ewing, L.L. \& McDonald, L.E. (1969) Peripheral plasma progesterone levels during the bovine oestrous cycle. J. Reprod. Fert. 19, 433-439.

Stickland, N.C. \& Purton, M.D. (1977) A quantitative evaluation of placentome development in Zebu cattle (Bos indicus). Zentbl. VetMed. C; Anat. Histol. Embryol. 6, 81-86.

Stott, G.H. \& Williams, R.J. (1962) Causes of low breeding efficiency in dairy cattle associated with seasonal high temperatures. J. Dairy Sci. 45, 1369-1375.

Summers, A.M., Shelton, J.N. \& Edwards, J. (1983) The production of mixed species Bos taurus-Bos indicus twin calves. Anim. Reprod. Sci. 6, 79-89.

Tanabe, T.Y. \& Brofee, R.D. (1982) Treatment of cystic ovarian follicles in dairy cows with chorionic gonadotrophin. Theriogenology 18, 497-512.

Tervit, H.R., Fairclough, R.J., McGowan, L.T., Mackenzie, D.D.S., Macmillan, K.L. \& Peterson, A.J. (1980) Induction of lactation in dry dairy cattle. N.Z. vet. J. 28, 15-19.
Thatcher, W.W., Wilcox, C.J., Collier, R.J., Diann, S.E. \& Head, H.H. (1980) Bovine conceptus-maternal interactions during pre- and post-partum periods. $J$. Dairy Sci. 63, 1530-1540.

Thatcher, W.W., Wolfenson, D., Curl, J.S., Rico, L.E., Knickerbocker, J.J., Bazer, F.W. \& Drost, J. (1984) Prostaglandin dynamics associated with development of the bovine conceptus. Anim. Reprod. Sci. 7, 149-176.

Turner, J.W. (1980) Genetic and biological aspects of Zebu adaptability. J. Anim. Sci. 50, 1201-1205.

Vaca, L.A., Galina, C., Fernandez-Baca, S., Escobar, J. \& Ramirez, B. (1983) Progesterone levels and relationship with the diagnosis of a corpus luteum by rectal palpation during the estrous cycle in Zebu cows. Theriogenology 20, 67-76.

Vaillancourt, D., Bierschwal, C.J., Ogwu, D., Elmore, R.G., Martin, C.E., Sharp, A.J. \& Youngquist, R.S. (1979) Correlation between pregnancy diagnosis by membrane slip and embryonic mortality. $J$. Am. vet med. Assoc. 175, 466-468.

VanDemark, M.L. \& Salisbury, G.W. (1950) The relation of the post partum breeding interval to reproductive efficiency in dairy cows. J. Anim. Sci. 9, 307-313.

Vandeplassche, M. \& Bouters, R. (1982) The impact of gynaecological and obstetrical problems resulting out of pregnancy and parturition. In Factors Influencing Fertility in the Post-partum Cow, pp. 30-44. Eds H. Karg \& E. Schallenberger. Martinus Nijhoff, The Hague.

Villa-Godoy, A., Ireland, J.J., Wortman, J.A., Ames, N.K. \& Fogwell, R.L. (1981) Luteal function in heifers following destruction of ovarian follicles on three stages of diestrus. J. Anim. Sci. 53 (Suppl. 1), 372, Abstr. 603.

Wagner, W.C. (1980) Parturition induction in cattle. In Current Therapy in Theriogenology, pp. 236-238. Ed. D. A. Morrow. W. B. Saunders, Philadelphia.

Wagner, W.C. \& Li, P.S. (1982) Influence of adrenal corticosteroids on post partum pituitary and ovarian function. In Factors Influencing Fertility in the Post-partum Cow, pp. 197-219. Eds H. Karg \& E. Schallenberger. Martinus Nijhoff, The Hague.

Wagner, W.C., Saatman, R. \& Hansel, W. (1969) Reproductive physiology of the post partum cow. II. Pituitary, adrenal and thyroid function. J. Reprod. Fert. 18, $501-508$.

Walters, D.L. \& Schallenberger, E. (1984) Pulsatile secretion of gonadotrophins, ovarian steroids and ovarian oxytocin during the periovulatory phase of the oestrous cycle in the cow. J. Reprod. Fert. 71, 503-512.

Walters, D.L., Schams, D. \& Schallenberger, E. (1984) Pulsatile secretion of gonadotrophins, ovarian steroids and ovarian oxytocin during the luteal phase of the oestrous cycle in the cow. J. Reprod. Fert. 71, 479-491.

Wathes, D.C. (1984) Review. Possible actions of gonadal oxytocin and vasopressin. J. Reprod. Fert. 71, 315-345.

Watson, E.D. \& Munro, C.D. (1980) A re-assessment of the technique of rectal palpation of corpora lutea in cows. Br. vet. J. 136, 555-560.

Webb, R., Lamming, G.E., Haynes, N.B., Hafs, H.D. \& Manns, J.G. (1977) Response of cyclic and post 
partum suckled cows to injections of synthetic LH-RH. J. Reprod. Fert. 50, 203-210.

Webb, R., Lamming, G.E., Haynes, N.B. \& Foxcroft, G.T. (1980) Plasma progesterone and gonadotrophin concentrations and activity in post-partum dairy cows. J. Reprod. Fert. 59, 133-143.

Wells, P.L., Holness, D.H., Freymark, P.J., McCabe, C.T. \& Lishman, A.W. (1985) Fertility in the Afrikaner cow. 2. Ovarian recovery and conception in suckled and non-suckled cows post partum. Anim. Reprod. Sci. 8, 315-326.

Wendorf, G.L., Lawyer, M.S. \& First, N.L. (1983) Role of the adrenals in the maintenance of pregnancy in cows. J. Reprod. Fert. 68, 281-287.

Willemse, A.H., Nieuwenhuis, H.U.R., Dieleman, S.J. \& Pieterse, M.C. (1982) Treatment of true anoestrus in dairy cows with a progesterone releasing intravaginal device (PRID). In Factors Influencing Fertility in the Post-partum Cow, pp. 536-541. Eds H. Karg \& E. Schallenberger. Martinus Nijhoff, The Hague.

Williams, G.L. \& Ray, D.E. (1980) Hormonal and reproductive profiles of early post partum beef heifers after prolactin suppression or steroid induced luteal function. J. Anim. Sci. 50, 906-918.

Williamson, N.B., Morris, R.S., Blood, D.C., Cannon, C.M. \& Wright, P.J. (1972a) A study of oestrous behaviour and oestrus detection methods in a large commercial dairy herd. II. Oestrous signs and behaviour patterns. Vet. Rec. 91, 58-62.

Williamson, N.B., Morris, R.S., Blood, D.C. \& Cannon, C.M. (1972b) A study of oestrous behaviour and oestrus detection methods in a large commercial dairy herd. Vet. Rec. 91, 50-58.
Wiltbank, J.N., Kasson, C.W. \& Ingalls, J.E. (1969) Puberty in crossbred and straightbred beef heifers on two levels of feed. J. Anim. Sci. 29, 602-605.

Winters, L.M., Green, W.W. \& Comstock, R.E. (1942) Prenatal development of the bovine. Tech. Bull. Minn. Agric. Exp. Stn, No. 151.

Wishart, D.F., Young, I.M. \& Drew, S.B. (1977) Fertility of norgestomet treated dairy heifers. Vet. Rec. 100, $417-420$.

Wolford, E. \& Argoudelis, O. (1970) Measurement of estrogens in cows' milk, human milk and dairy products. J. Dairy Sci. 62, 1458-1463.

Wurster, D.H. \& Benirschke, K. (1968) Chromosome studies in the super family Bovoidae. Chromosoma 25, $152-171$

Youdan, P.G. \& King, J.O.L. (1977) The effects of body weight changes on fertility during the post partum period in dairy cows. Br. vet. $J .133,635-641$.

Young, G.B., Lee, G.E., Waddington, D., Sales, D.I., Bradley, J.S. \& Spooner, R.L. (1983) Culling and wastage in dairy cows in East Anglia. Vet. Rec. 113, 107-111.

Zimbleman, R.G., Loy, R.G. \& Casida, L.E. (1961) Variations in some biochemical and histological characteristics of bovine corpora lutea during early pregnancy. J. Anim. Sci. 20, 99-105.

Received 31 December 1984 